\title{
Evolution of Deformation Studies on Active Hawaiian Volcanoes
}

Scientific Investigations Report 2008-5090 
This page intentionally left blank 


\section{Evolution of Deformation Studies on Active Hawaiian Volcanoes}

By Robert Decker, Arnold Okamura, Asta Miklius, and Michael Poland

Scientific Investigations Report 2008-5090 


\title{
U.S. Department of the Interior \\ DIRK KEMPTHORNE, Secretary
}

\author{
U.S. Geological Survey \\ Mark D. Myers, Director
}

U.S. Geological Survey, Reston, Virginia: 2008

For product and ordering information:

World Wide Web: http://www.usgs.gov/pubprod

Telephone: 1-888-ASK-USGS

For more information on the USGS--the Federal source for science about the Earth, its natural and living resources, natural hazards, and the environment:

World Wide Web: http://www.usgs.gov

Telephone: 1-888-ASK-USGS

Any use of trade, product, or firm names is for descriptive purposes only and does not imply endorsement by the U.S. Government.

Although this report is in the public domain, permission must be secured from the individual copyright owners to reproduce any copyrighted materials contained within this report.

Suggested citation:

Decker, Robert, Okamura, Arnold, Miklius, Asta, and Poland, Michael, 2008, Evolution of deformation studies on active Hawaiian volcanoes: U.S. Geological Survey Scientific Investigations Report 2008-5090, 23 p.

Cataloging-in-Publication data are on file with the Library of Congress (URL http://www.loc.gov/).

Produced in the Western Region, Menlo Park, California

Manuscript approved for publication, May 22, 2008

Text edited by Tracey Suzuki

Layout and design by Luis Menoyo 


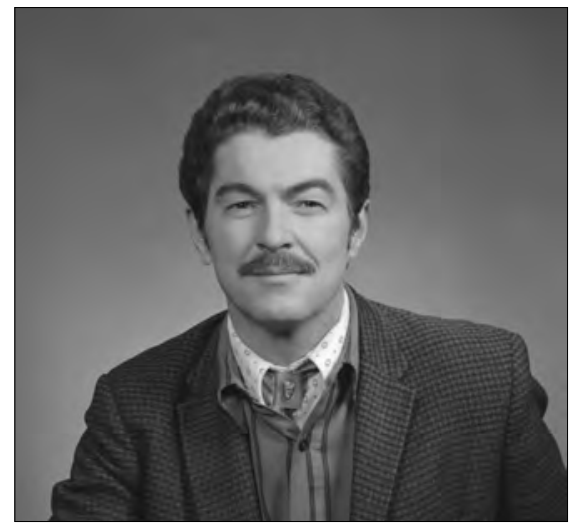

(Photo credit: Dartmouth College Archive)

\section{Preface}

Robert (Bob) Decker was a volcanological pioneer, introducing new technologies for making deformation measurements at active volcanoes and pushing volcanology into new and exciting frontiers. During his time as a professor at Dartmouth College, Bob explored new methods for quantitatively modeling volcano deformation while working at locales in the United States, Central and South America, Iceland, and Indonesia. In the mid-1960s, Bob introduced Electronic Distance Measurement as a tool for monitoring volcano deformation and began measurements at Kilauea and Mauna Loa volcanoes in Hawai' i. This contribution ushered in a new age of high-precision volcano geodesy. In 1979, Bob left Dartmouth to take the position of Scientistin-Charge of the U.S. Geological Survey's Hawaiian Volcano Observatory, a post that he held until 1984. Hardly letting his 1989 retirement slow him down, Bob worked closely with his wife Barbara to publish numerous road guides and several volcanological texts, including Volcanoes in America's National Parks.

Throughout his career, Bob worked tirelessly toward fostering international collaborations in volcanology, serving as the president of the International Association of Volcanology and Chemistry of the Earth's Interior from 1975 to 1979 . One of his most influential contributions was the creation of the Center for the Study of Active Volcanoes at the University of Hawai i, Hilo, in 1989, which has since trained hundreds of scientists from around the world-mostly from developing countries-in volcano-monitoring techniques.

Bob died on June 11, 2005. He was an enthusiastic and consummate innovator and a leading field and quantitative volcanologist. He also maintained a strong commitment to education and public outreach. His vision and leadership are sorely missed.

Bob began this work several years before his death. In completing Bob's manuscript, we strove to preserve his style, content, and original intent.

Arnold Okamura

Asta Miklius

Michael Poland

September 2006 
This page intentionally left blank 


\section{Contents}

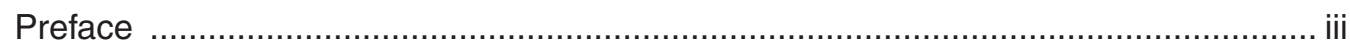

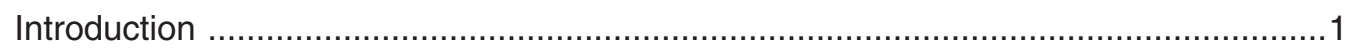

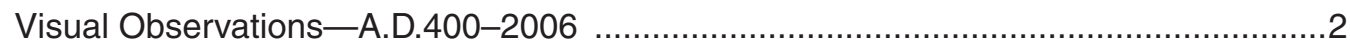

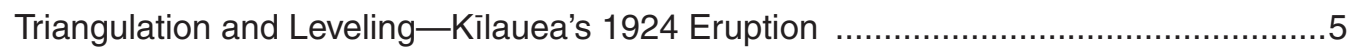

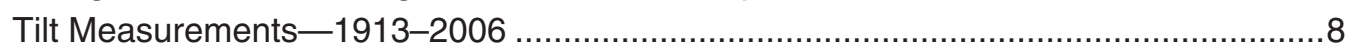

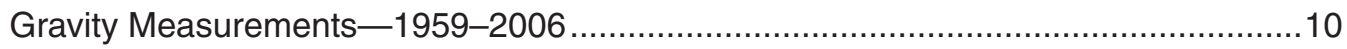

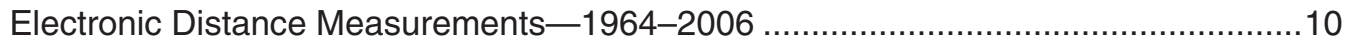

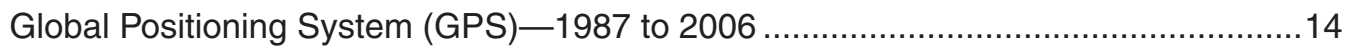

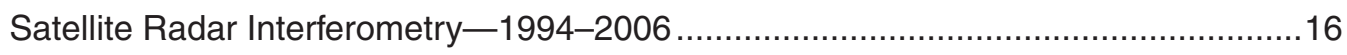

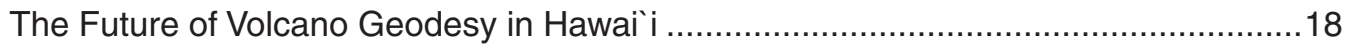

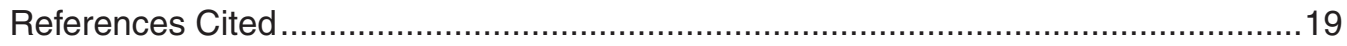

\section{Figures}

1. Elevation of the surface of Killauea Caldera lava lake as estimated by observers listed in table 1 ............................................................................

2. Horizontal displacements at the summit area of Kilauea Volcano from

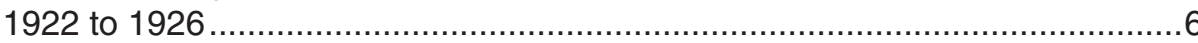

3. Contours of subsidence of the summit area of Kilauea Volcano

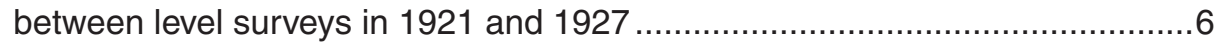

4. Time series of elevations of benchmark SPIT in southern part of Kilauea's caldera from 1921 through 2005.

5. Lateral shift of the apex of uplift of inflating bulge on the summit of Kilauea as measured by ten level surveys from January 1966 to October 1967 ...........7

6. North-south and west-east tilt from 1956 through 2005 at the Uwēkahuna water-tube tiltmeter.... .8

7. Comparison of elevation changes of the summit area of Kilauea Volcano by leveling and tilt changes at Whitney Vault on the north rim of the caldera and Uwēkahuna Vault on the west rim of the caldera. 3 (1)

. Gravity changes versus elevation changes during the Pu'u 'Ō'ō-Kupaianaha eruption, along with changes in distance across Kïlauea's caldera...

9. Extension of Mauna Loa's caldera before, during, and after the1975 and 1984 eruptions as measured by EDM, and later by GPS, along lines between benchmarks MOKP and HVO92, and MOKP and MLSP.....

10. Displacements on Kilauea Volcano related to the $1975 \mathrm{M}=7.2$ earthquake.

11. Changes in distance across the south flank of Kilauea Volcano since 1970 as measured along a 8.6-km-long line across the Hilina fault system to the sea between benchmarks Goat and Apua Point

12. Line length change across Kilauea's summit caldera from 1996 through 2005. 
13. A rapid increase in distance across the summit caldera started in May 2002

14. Horizontal velocities measured by both survey and continuous GPS measurements from 1997 to 2002, and from 2002 to 2004

15. Interferogram made from ENVISAT images acquired on January 27 , 2003, and June 20, 2005, showing deformation between those two time periods.....

16. ENVISAT interferograms spanning from July 2, 2003, to September 29, 2004 and from September 29, 2004, to December 28, 2005

\section{Tables}

1. Lava levels in Kïlauea Caldera, 1823-1912 ................................................

2. Estimates of volume lost during episodes of Killauea Caldera lava lake withdrawal, in millions of cubic meters ............................................................4

3. Lava levels in Halema` uma 'u Crater, 1924-2006 ..........................................4 


\title{
Evolution of Deformation Studies on Active Hawaiian Volcanoes
}

\author{
By Robert Decker, Arnold Okamura, Asta Miklius, and Michael Poland
}

\section{Introduction}

\section{Everything responds to pressure, even rocks.}

Deformation studies involve measuring and interpreting the changes in elevations and horizontal positions of the land surface or sea floor. These studies are variously referred to as geodetic changes or ground-surface deformations and are sometimes indexed under the general heading of geodesy. Deformation studies have been particularly useful on active volcanoes and in active tectonic areas.

A great amount of time and energy has been spent on measuring geodetic changes on Kīlauea and Mauna Loa Volcanoes in Hawai' i. These changes include the build-up of the surface by the piling up and ponding of lava flows, the changes in the surface caused by erosion, and the uplift, subsidence, and horizontal displacements of the surface caused by internal processes acting beneath the surface. It is these latter changes that are the principal concern of this review.

A complete and objective review of deformation studies on active Hawaiian volcanoes would take many volumes. Instead, we attempt to follow the evolution of the most significant observations and interpretations in a roughly chronological way. It is correct to say that this is a subjective review. We have spent years measuring and recording deformation changes on these great volcanoes and more years trying to understand what makes these changes occur. We attempt to make this a balanced as well as a subjective review; the references are also selective rather than exhaustive.

Geodetic changes caused by internal geologic processes vary in magnitude from the nearly infinitesimal —one micron or less, to the very large - hundreds of meters. Their apparent causes also are varied and include changes in material properties and composition, atmospheric pressure, tidal stress, thermal stress, subsurface-fluid pressure (including magma pressure, magma intrusion, or magma removal), gravity, and tectonic stress.

Deformation is measured in units of strain or displacement. For example, tilt of the ground surface on the rim of Kîlauea Caldera is measured in microradians, a strain unit that gives the change in angle from some reference. The direction in which the tilt is measured must be defined - north or south, or some direction normal to the maximum changes.
For displacements related to surface faulting, the changes are normally given in linear measures of offset. Changes in the diameter of a caldera can be given in either displacements or strain units. In the later case, the displacement divided by the "original" diameter gives the strain ratio. Strains are dimensionless numbers; displacements have the dimensions of length. Vectors commonly are used to show the direction and amount of displacements in plan view.

Strain results from stress. It can be elastic strain, when the strain is linearly related to stress and is recoverable; it can be viscous strain, where the rate of strain is proportional to the stress and is not recoverable; or it can be plastic strain that is often some complex stress-strain relationship, for example, elastic up to some yield strength and viscous beyond. Volcanic rocks are brittle when cold and under near-surface pressures but plastic to viscous under higher temperature and pressure regimes. It is important in deformation studies to try to define the nature of the strain and the rheology of the rocks being deformed. A good text on rheology is "The Structure and Rheology of Complex Fluids” by R.G. Larson, 1999.

Under changing tensional or compressional stresses, tiny cracks in brittle rocks may open or close, causing a quasielastic strain response. If the stresses exceed the breaking strength of the rock, brittle failure occurs, and the stress-strain relationship breaks down. This is generally the situation with near-field deformation related to earthquakes. Stresses change in complex patterns in both the near- and far-fields of the fracture, and the near-field fracture displacements cannot be measured in strain units.

Deformations of the ground surface on Kìlauea and Mauna Loa result from the sum of complex causes. Nevertheless, deformation studies have been helpful in understanding the subsurface processes of these volcanoes and also offer great promise toward eruption forecasting.

The organization of the following report reviews these deformation studies in chapters that discuss the beginning and the application of different techniques for observing, measuring, and interpreting geodetic changes on Kīlauea and Mauna Loa. The techniques have evolved, but the earliest technique, visual observation, is still important and continues to be used today. Many of the techniques are complementary; for example, using GPS and satellite measurements of benchmark 
positions provides "ground truth" for InSAR (satellite radar interferometry) maps. As new techniques evolve, it is important not to abandon earlier measurements - especially those with long observational records. However, it may be difficult or impossible to quantitatively correlate older and newer observations. A human lifetime is but a moment in the historic and prehistoric activity of Kỉlauea and Mauna Loa. The longer the record of observations, the better the possibility of understanding how these complex and dynamic volcanoes operate.

\section{Visual Observations- A.D.400-2006}

\section{"The chief characteristic of Halemaumau is change.” E.S. Shepard}

The ancient Hawaiians were excellent observers of their landscape. They had no written language, but the information they recorded in chants and oral legends is important and has the advantage of more than 1,400 years of observation. Many legends in various parts of the world are based on real events that occurred in the past, and this seems to be the case with regard to some legends about Hawaiian volcanoes. We begin with the comments made to William Ellis (1825) by his Hawaiian guides. Ellis visited Kîlauea in 1823. Besides being fluent in the Hawaiian language, he was the first to publish a journal about visiting Kīlauea Caldera. Ellis (1825) wrote:

Native Traditions Concerning Volcano: As eight of the natives with us belonged to the adjoining district, we asked them to tell us what they knew of the history of this volcano, and what their opinions were respecting it. From their account, and that of others with whom we conversed, we learned, that it had been burning from time immemorial, or, to use their own words, "mai ka po mai," from chaos till now, (the Hawaiian traditions, like those of the ancients, refer to night, or a chaotic state, the origin of the world, and almost all things therein, the greater part of their gods not excepted, the present state they call the Ao marama, Day, or state of light; they speak of creation as a transition from darkness to light; and when they wish to express the existence of any thing from the beginning, they say it has been so mai ka po mai, from the night, or state of darkness or confusion, till now;) and had overflowed some part of the country during the reign of every king that had governed Hawai $i$ : that in earlier ages it used to boil up, overflow its banks, and inundate the adjacent country; but that, for many kings' reigns past, it had kept below the level of the surrounding plain, continually extending its surface and increasing its depth, and occasionally throwing up, with violent explosion, huge rocks or red-hot stones. These eruptions, they said, were always accompanied by dread- ful earthquakes, loud claps of thunder, with vivid and quick-succeeding lightning. No great explosion, they added, had taken place since the days of Keoua; but many places near the sea had since been overflowed, on which occasions they supposed Pele went by a road under ground from her house in the crater to the shore.

These few facts were gathered from their accounts of its origin and operation; but they were so incorporated with their traditions of its supernatural inhabitants, and fabulous stories of their romantic adventures, that we found no small difficulty in distinguishing fiction from fact.

Fact and fiction are always difficult to distinguish, but in our opinion there is much more fact than fiction in this account by Ellis' guides. Some important pieces of information can be inferred from these comments, for example, that lava flowed outward from the summit crater region since the settlement of the islands (this has been confirmed by radiocarbon dating by Clague and others, 1999), and that activity, including explosive eruptions, was limited to the caldera "for many kings' reigns past," which is the first written suggestion that the caldera predates 1790 . The latest explosion occurred in 1790 during the reign of Keoua. Ellis also writes that many places near the sea had been overrun by lava flows, "on which occasions $* * *$ [the Hawaiians] supposed Pele went by a road under ground from her house in the crater to the shore." This is the first description, and it is both clear and succinct, of lava tubes on Hawaiian volcanoes.

Ellis was also the first to recognize that Kîlauea's caldera had formed by subsidence. When describing his first view of Kîlauea Caldera he notes "**** we found ourselves on the edge of a steep precipice, with a vast plain before us, fifteen or sixteen miles in circumference, and sunk from 200 to 400 feet below its original level." The key word is "sunk". Although it would be many years until Clarence Dutton (1884) introduced the term "caldera" to describe the huge summit depressions of Kîlauea and Mauna Loa, Ellis was the first to publish this important concept of subsidence at the summit of Kîlauea.

When Asa Bishop (1827) revisited Kîlauea in 1826, he noted that much new lava had filled the caldera, and he was informed by his Hawaiian guides that, "after rising a little higher, the lava will discharge itself, as formerly, towards the sea, through some aperture underground." Although this forecast of future activity of Kīlauea was not time specific, it was correct.

Many observers, some of them repeated visitors, made visual estimates of the increasing and decreasing lava levels in Killauea's caldera during the 19th century. Figure 1, based on table 1, summarizes these changes. Most of the early estimates were rough at best, and there are many gaps during times when no one visited the caldera or recorded their observations. Nevertheless, even qualitative estimates of the addition or withdrawal of lava from the summit caldera provide important data about the pressure or volume changes occurring in the magma reservoir beneath it. For clarity, we 
refer to the elevation of the active lava lake in the caldera as the top of Killauea's lava column. For the later part of the 19th century, that active lava lake often is referred to as being in Halema uma u Crater, a pit crater within the caldera. At times, when the top of the lava column subsides below the surface, a deep, empty pit is formed. When that occurs, the elevation of the top of the lava column is deeper than the bottom of the empty crater by some unknown amount.

After the Hawaiian Volcano Observatory (HVO) was established by Thomas Jaggar in 1912, more continuous and more quantitative observations of the lava column in Hale uma u Crater's active lava lake were made. Many of these involved measuring vertical angles with a theodolite (a surveying instrument that can be rotated vertically to measure angels). In this way, purely visual observations began to merge and be replaced by instrumental observations. From 1823 to 1924 , the slow accumulation and rapid withdrawal of the molten lava lake in the caldera was the dominant activity of Kîlauea Volcano. Major withdrawal episodes, along with estimates of volumes lost, are listed in table 2. Smaller episodes occurred in 1849, 1855, 1871, 1879, and 1913 (Finch, 1940).

Lava-lake withdrawal was associated in 1823 with a flank eruption on the southwest rift zone (SWRZ); in 1832 with a summit eruption just west of Kīlauea Iki Crater; in 1840 with an eruption on the east rift zone (ERZ); and in 1868 with a small eruption on the SWRZ and, probably of more importance, the estimated M7.9 Ka'u earthquake (Wyss and Koyanagi, 1992). The 1886 lava lake withdrawal was not associated with an eruption, but there was an earthquake swarm. The same relation holds for the 1891, 1894, and 1916 withdrawal events. A SWRZ eruption in 1920 was accompanied by lower-

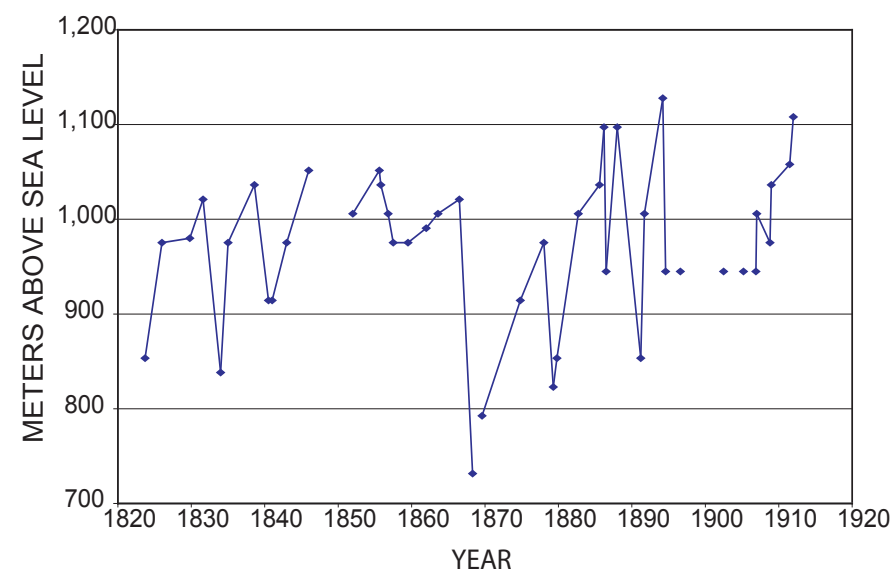

Figure 1. Elevation of the surface of Kilauea Caldera lava lake as estimated by observers listed in table 1. A line between observation points indicates that the lava lake surface was apparently visible, but not measured. No line between observation points indicates the lava column was apparently below the visible ground surface.
Table 1. Lava levels in Kìlauea Caldera, 1823-1912.

\begin{tabular}{|c|c|c|}
\hline Date & $\begin{array}{l}\text { Elevation above } \\
\text { sea level, meters }\end{array}$ & Source \\
\hline Aug 1823 & 853.44 & Ellis (1825) \\
\hline Dec 1826 & 975.36 & Bishop (1827) \\
\hline Jul 1831 & 1021.08 & Goodrich (1831) \\
\hline Jan 1834 & 838.20 & Douglas (1834) \\
\hline 1835 & 975.36 & Hitchcock (1911) \\
\hline Jul 1838 & 1036.32 & Strzelecki (1838) \\
\hline Jun 1840 & 914.40 & Coan ${ }^{1}$ \\
\hline Dec 1840 & 914.40 & Wilkes (1845) \\
\hline 1843 & 975.36 & Pickering (1844) \\
\hline 1846 & 1051.56 & Lyman (1851) \\
\hline 1852 & 1005.84 & Coan $^{1}$ \\
\hline Jul 1855 & 1051.56 & Coan $^{1}$ \\
\hline Oct 1855 & 1036.32 & Coan $^{1}$ \\
\hline Oct1856 & 1005.84 & Coan $^{1}$ \\
\hline Jun 1857 & 975.36 & Coan $^{1}$ \\
\hline Jun 1859 & 975.36 & Haskell (1860) \\
\hline 1862 & 990.60 & Coan $^{1}$ \\
\hline Jul 1863 & 1005.84 & Coan $^{1}$ \\
\hline Jun 1866 & 1021.08 & Coan $^{1}$ \\
\hline Apr 1868 & 731.52 & Coan $^{1}$ \\
\hline Jul 1869 & 792.48 & Coan $^{1}$ \\
\hline Oct 1874 & 914.40 & Coan $^{1}$ \\
\hline Jan 1878 & 975.36 & Hitchcock (1911) \\
\hline Apr 1879 & 822.96 & Coan $^{1}$ \\
\hline Oct 1879 & 853.44 & Hitchcock (1911) \\
\hline Aug 1882 & 1005.84 & Hitchcock (1911) \\
\hline Jul 1885 & 1036.32 & Hitchcock (1911) \\
\hline Mar 1886 & 1097.28 & Hitchcock (1911) \\
\hline Jun 1886 & 944.88 & Hitchcock (1911) \\
\hline 1888 & 1097.28 & Hitchcock (1911) \\
\hline Mar 1891 & 853.44 & Hitchcock (1911) \\
\hline Sep 1891 & 1005.84 & Hitchcock (1911) \\
\hline Mar 1894 & 1127.76 & Hitchcock (1911) \\
\hline Jul 1894 & 944.88 & Hitchcock (1911) \\
\hline Jul 1896 & 944.88 & Bevens (1992) \\
\hline Jun 1902 & 944.88 & Bevens (1992) \\
\hline Feb 1905 & 944.88 & Hitchcock (1911) \\
\hline Dec 1906 & 944.88 & Hitchcock (1911) \\
\hline Jan 1907 & 1005.84 & Hitchcock (1911) \\
\hline Sep 1908 & 975.36 & Brigham (1908) \\
\hline Dec 1909 & 1036.32 & Hitchcock (1911) \\
\hline Jul 1911 & 1058.00 & Bevens and others (1988) \\
\hline Jan 1912 & 1108.00 & Bevens and others (1988) \\
\hline
\end{tabular}

ing of the lava lake in Halema uma 'u Crater, although the lake remained active. Molten lava was seen pouring southwestward from the lava lake through a rift-zone fissure during the 1920 eruption (Stearns and Macdonald, 1946). Withdrawal in 1922 was accompanied by an eruption on the ERZ and in 1924 by an explosive summit eruption, earthquake swarm, and graben formation on the ERZ (Jaggar and Finch, 1924; Stearns, 1925; Decker and Christiansen, 1984).

At least 100 years of dominantly lava-lake activity in Kîlauea's caldera, from 1823 to 1924, ended with the 1924 
Table 2. Estimates of volume lost during episodes of Killauea Caldera lava lake withdrawal, in millions of cubic meters (from Finch, 1941).

\begin{tabular}{lr}
\hline Year & Volume \\
\hline 1823 & 540 \\
1832 & 581 \\
1840 & 220 \\
1868 & 188 \\
1886 & 40 \\
1891 & 34 \\
1894 & 8 \\
1916 & 7 \\
1919 & 10 \\
1922 & 21 \\
1924 & 202 \\
Total & $\mathbf{1 , 8 5 1}$ \\
\hline
\end{tabular}

subsidence. Halema`uma`u Crater was more than 400-m deep after that event; the lava column was, thus, below an elevation of about $700 \mathrm{~m}$, compared to about $900 \mathrm{~m}$ at the time of Ellis' visit in 1823. Finch (1941) and Stearns and Macdonald (1946) estimated the accumulated net volume during that 100 -year interval to be about $0.9 \mathrm{~km} 3$, and the total summit production to be about $2.9 \mathrm{~km} 3$, including the volumes withdrawn during the episodes of subsidence. Table 2 gives Finch's (1941) estimates of the volumes lost during the major episodes of subsidence.

Nine episodes of lava eruption partly refilled Halema uma u Crater between 1924 and 1954, only one of which, in 1952, lasted more than 100 days. The activity at Halema uma u Crater from 1924 to 2006 is summarized in table 3. The 1952 eruption returned the temporary lava-column level back to $145 \mathrm{~m}$ below its rim (963 m above sea level). In 1960, the ERZ eruption at Kapoho apparently caused an 85-m subsidence of the solidified lava surface in Halema uma $u$ Crater, 40-km distant. In 1967, eight short episodes of infilling and one long-lasting lava lake returned the lava level in Halema uma u Crater to $40 \mathrm{~m}$ below its rim (1,068 $\mathrm{m}$ above sea level). Subsidence in 1971 associated with a SWRZ eruption lowered the crusted-over bottom of Halema uma u by 50 $\mathrm{m}$. Three small eruptions in 1974, 1975, and 1982 refilled the bottom to $85 \mathrm{~m}$ below its rim (1,023 $\mathrm{m}$ above sea level), its approximate crusted-over depth in 2006. No eruptions at the summit of Kîlauea have occurred since the long-lasting ERZ eruption at Pu'u ' $\bar{O}^{\prime} \bar{o}$ began in 1983, and it is inferred that the top of the lava column is now far below the level of the present bottom of Halema uma u Crater. If so, why does the floor of Halema uma u Crater not collapse? One possible explanation is that the present plug of hardened lava in the crater is too strong to collapse.

Besides the ups and downs of the lava levels in the active lava lakes, there was a significant domal uplift of the crustedover lava lake in the central area of Kîlauea Caldera between
Table 3. Lava levels in Halema`uma`u Crater, 1924-2006, after Hazlett (1993).

\begin{tabular}{lrl}
\hline Year & $\begin{array}{c}\text { Elevation, } \\
\text { meters }\end{array}$ & \multicolumn{1}{c}{ Remarks } \\
\hline 1924 & 698 & After subsidence in May \\
1924 & 713 & July eruption, 11 days \\
1927 & 753 & 40-m cone built at bottom in 13 days \\
1929 & 783 & 2 short eruptions, 6 days total \\
1930 & 798 & 19-day eruption \\
1931 & 838 & 14-day eruption \\
1934 & 883 & 33-day eruption \\
1952 & 958 & 136-day eruption \\
1954 & 963 & 3-day eruption \\
1960 & 878 & crust collapses, east rift zone eruption \\
1961 & 978 & 3-short-lived eruptions \\
$1967-68$ & 1,068 & 251-day eruption \\
1971 & 1,018 & crust collapses, southwest rift zone \\
& & eruption \\
1974 & 1,023 & < 1-day eruption \\
1975 & 1,023 & < 1-day eruption \\
1982 & 1,023 & $<$ 1-day eruption \\
\hline
\end{tabular}

1840 and 1846 (Lyman, 1851). Lyman's 1846 sketch map shows an area about 1 mile in diameter that had been uplifted $30-50 \mathrm{~m}$ above the "black ledge" - the lava level just prior to the 1840 subsidence.

Major sags of the crusted-over lava lake occurred in 1868 and 1960 and were associated with rift eruptions. In 1869, Coan (1870) describes the central area of Kîlauea Caldera as an immense pit where the crust subsided $120-150 \mathrm{~m}$ as one piece, leaving plants still growing on it. In 1960, the floor of Halema uma u Crater fell 100 m on February 7, four days after the start of the Kapoho (lower ERZ) eruption (Richter and others, 1970).

The formation of a crater was observed during the 1955 ERZ eruption, the first eye-witness account of collapse along a rift zone. At 16:03 on March 20, a sharp explosion from one of the vent areas, only about 45-m east of the Kalapana road, threw dark ash $150 \mathrm{~m}$ into the air. Air reconnaissance revealed a nearly circular pit with a mouth about $10-\mathrm{m}$ in diameter and a brightly glowing interior. The edges of the pit caved back rapidly during the next few days, revealing it to be about 10-m deep and floored with talus from the collapsing rim (Macdonald, 1959).

In January 1997, the crater floor of Pu'u 'O' 'ō on the ERZ of Kîlauea suddenly dropped $150 \mathrm{~m}$, and the west wall of the cone collapsed, enlarging the elliptical crater to 240 by $400 \mathrm{~m}$ (Heliker and others, 2003).

The first written description of the summit caldera of Mauna Loa predates Ellis' first account of Kīlauea by 29 
years. Archibald Menzies, botanist with the Vancouver's voyage to the Hawaiian Islands, successfully climbed Mauna Loa in 1794 (Barnard, 1990). He determined the elevation of Mauna Loa by barometer to be $4,156 \mathrm{~m}$, remarkably close to the presently accepted elevation of 4,160 m. Menzies estimated the "Crater" to be about $1.5-\mathrm{km}$ in diameter and 365-meters deep. Visits to the summit of Mauna Loa were rare during the 19th century, as it did not contain an active, longlived lava lake like that in Kîlauea. Jaggar (1931) summarized the historical changes to the floor of Mauna Loa Caldera as being caused mainly by lava ponding during summit eruptions. Jaggar infers $27 \mathrm{~m}$ of subsidence between 1841 and 1874 , related to flank eruptions in $1843,1852,1855,1859$, and 1868. The ponded flows on the floor of the caldera in 2005 had an elevation of about $3,960 \mathrm{~m}$, roughly $200 \mathrm{~m}$ below the highest point on the caldera rim. This suggests a cumulative depth of $165 \mathrm{~m}$ of lava ponding in the caldera of Mauna Loa during the past 210 years.

\section{Triangulation and Leveling- Kīlauea's 1924 Eruption}

\section{"Owyhee has two snow-covered peaks, Mauna Roa and Mauna Kaa.” James Cook, 1779}

The use of transits and barometers to measure horizontal and vertical positions on Hawaiian volcanoes began with Captain Cook's voyage in 1779. King (1785) notes that the elevation of Mauna Loa was estimated to be $4,882 \mathrm{~m}$ on the basis of vertical angles taken from established points along the coast of Hawai i. As describd previously, Menzies climbed Mauna Loa in 1794 and determined its summit to be $4,156 \mathrm{~m}$ by barometer (Hitchcock, 1911). Lt. Malden with the British Lord Byron's expedition in 1825 apparently used a measured base line and transit to make the first map of Killauea's caldera (Stewart 1826).

Systematic triangulation surveying of the Islands by the Hawaiian Government began in 1871 (Mitchell, 1930; U.S. Coast and Geodetic Survey, 1969). This survey included Mauna Loa, whose summit elevation was determined in 1885 by vertical angles to be $4,168 \mathrm{~m}$ (J.M. Alexander, in Hitchcock, 1911). In 1926 the U.S. Coast and Geodetic Survey (USCGS) ran a First Order level line from Hilo to the summit of Mauna Loa and found the volcano's elevation by this more precise method to be $4,169 \mathrm{~m}$. This leveling was a tedious and expensive procedure that took more than six weeks - more than 3,000 "setups" - and a crew of five as well as packers to supply the survey campsites at higher elevations.

It was not until after the establishment of the Hawaiian Volcano Observatory (HVO) in 1912 that triangulation and leveling techniques proved useful for measuring geodetic changes. Leveling at Kîlauea in 1921, compared to an earlier leveling survey in 1912, showed an apparent rise of the Volcano House benchmark of $1 \mathrm{~m}$. However, the apparent change might have been due to rod-length error. It was the differences in both level and triangulation surveys around Kîlauea's caldera, related to the 1924 subsidence and explosive eruptions of Halema uma u Crater, that confirmed the large scale of measurable elevation and horizontal changes (Wilson, 1927a; 1935). Figure 2 shows the horizontal changes in the Kîlauea summit area between 1922 and 1926, and figure 3 shows the vertical changes in the area between 1921 and 1927. The caldera area around Halema uma u Crater subsided concentrically by as much as $4 \mathrm{~m}$ relative to the Volcano House benchmark, and triangulation points moved toward Halema uma u Crater by as much as $1.6 \mathrm{~m}$. The changes were too large to be ascribed to survey error, and their patterns were complementary. These classic surveys by R.M. Wilson clearly established the importance of deformation changes related to Hawaiian volcanism.

Leveling to determine the elevation of SPIT benchmark in the southern portion of Kîlauea's caldera (440 m southeast of the southeast rim of Halema uma 'u Crater) began in 1921 and continues to the present. This benchmark is near the location of the maximum uplift and subsidence of Kîlauea's summit. Although this point has undergone many up and down cycles, it is interesting that the first leveling (1921) marked Kîlauea's highest point and more recent surveys (2005) marked its lowest point-about $5 \mathrm{~m}$ lower (fig. 4).

Fiske and Kinoshita (1969) made ten leveling surveys in the caldera from January 1966 to October 1967 that showed a net of $70 \mathrm{~cm}$ of summit inflation prior to the Halema uma u Crater eruption that began in November 1967. Their results revealed the remarkable shifts of the apex of uplift east and south of Halema uma u Crater as the inflation progressed (fig. $5)$.

Apparent geodetic changes related to the east-rift eruption of Kîlauea in 1955 prompted Macdonald and Eaton (1957) to request level surveys in the Puna area of the Island of Hawai i. These Puna area surveys were done by Yukio Yamamoto in 1957-58 and reported in an unpublished USGS report by R. J. Karren. Yamamoto's surveys, compared to level lines of 1912, 1921-22, and 1927, clearly established that geodetic changes occur on Kīlauea's ERZ as well as at its summit. HVO made repeat level surveys along the Pāhoa-Kaimū road beginning in 1964 (Decker, 1965). Progressive uplift of the rift zone measured during the next several years, during a period of no rift-zone eruptions, implied ongoing subsurface magma injection into the lower ERZ (Dieterich and Decker, 1975). The 1955 east-rift eruption also prompted new triangulation surveys in the Puna area (Lloyd, 1964).

In 1927, the USCGS constructed a tide gauge at Hilo so that leveling surveys could tie benchmark elevations to mean sea level in order to detect the arrival of tsunami waves (Wilson, 1927b). Review of the Hilo and Honolulu tide-gauge data by Moore $(1970,1987)$ indicates a slow but persistent increase in sea level. Moore concludes that $1.2 \mathrm{~mm}$ of the 4.1 $\mathrm{mm} /$ year increase at Hilo is due to absolute sea-level rise and that the remaining $2.9 \mathrm{~mm}$ is the result of slow subsidence of the island. 


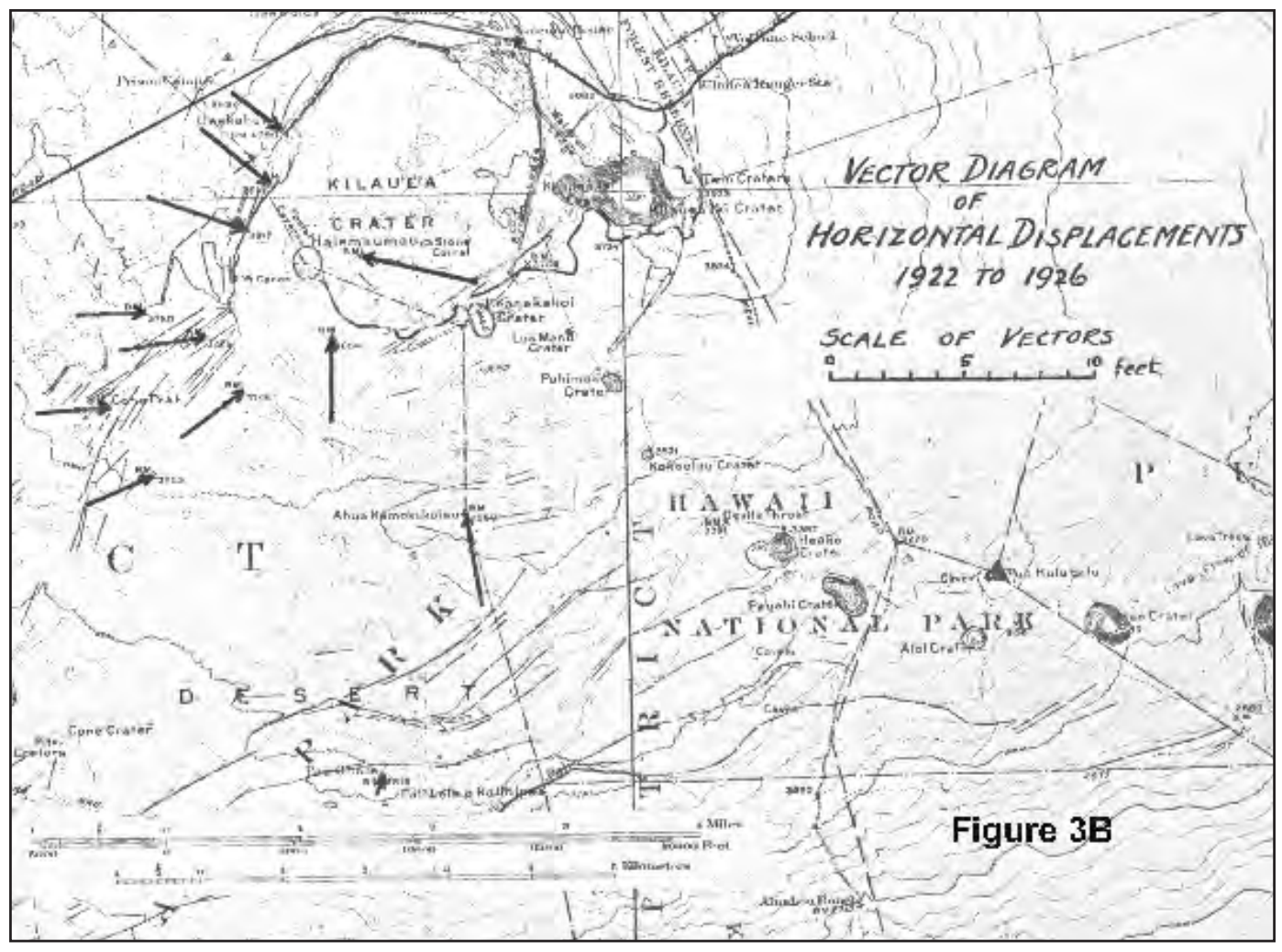

Figure 2. Horizontal displacements at the summit area of Kilauea Volcano from 1922 to 1926 (from Wilson, 1935).

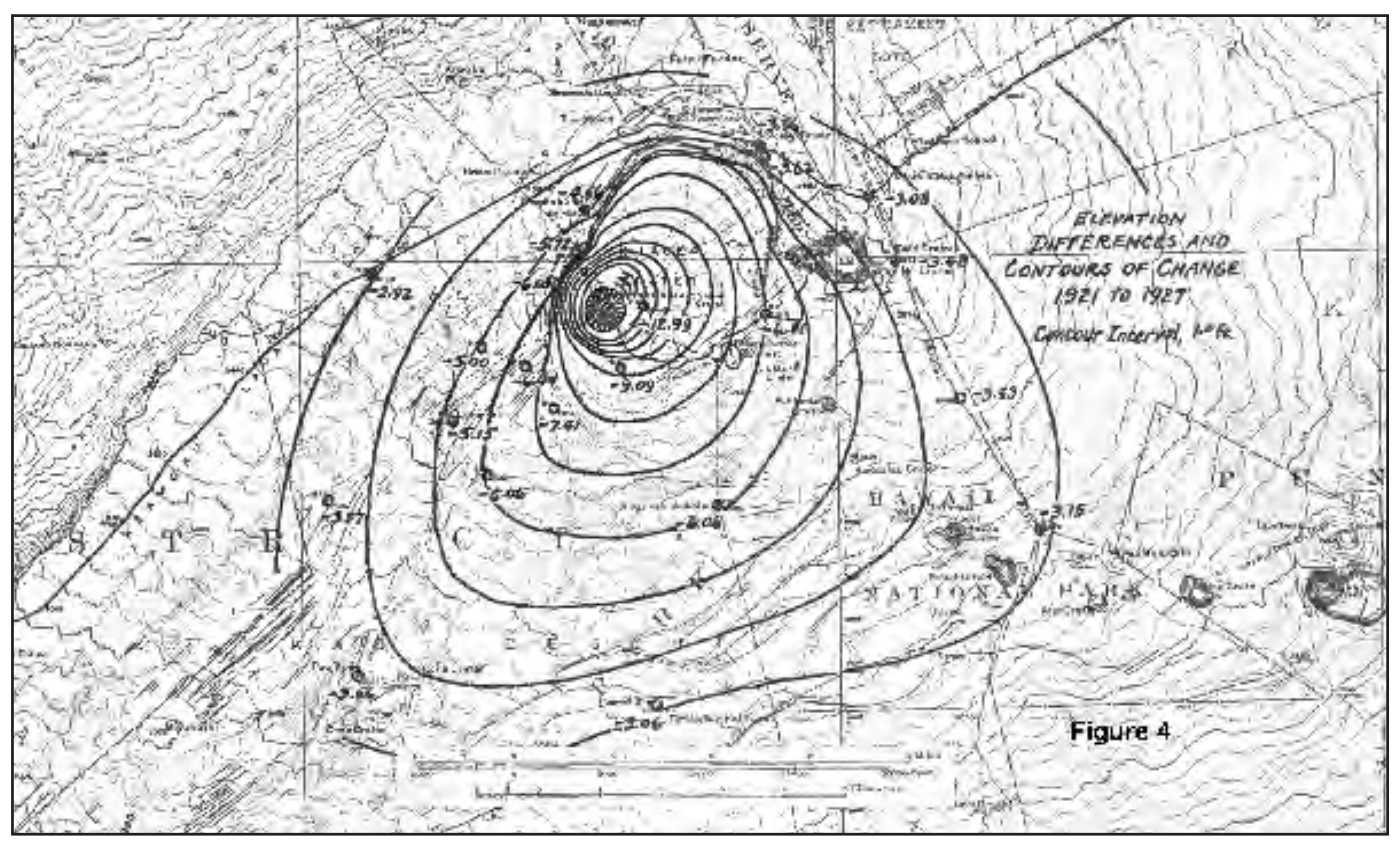

Figure 3. Contours of subsidence of the summit area of Kilauea Volcano between level surveys in 1921 and 1927. Note that the contour interval is 1 foot $(30 \mathrm{~cm})$ ! Most of this subsidence was apparently related to the more than $400 \mathrm{~m}$ drop of the lava column in Halema`uma`u Crater in 1924 (from Wilson, 1935). 


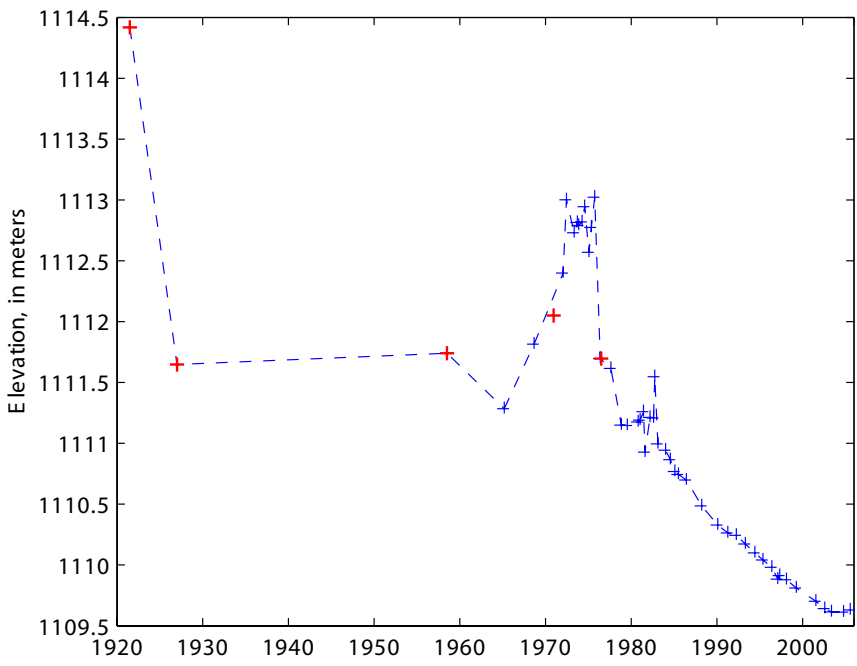

Figure 4. Time series of elevations of benchmark SPIT in southern part of Kilauea's caldera from 1921 through 2005. Red points indicate elevations relative to Hilo, blue are relative to benchmark HVO23, a few kilometers northwest of Kilauea's caldera. The 1921 and 1927 data are from Wilson (1935); the rest of the data are from U.S. Geological Survey's Hawaiian Volcano Observatory archives.

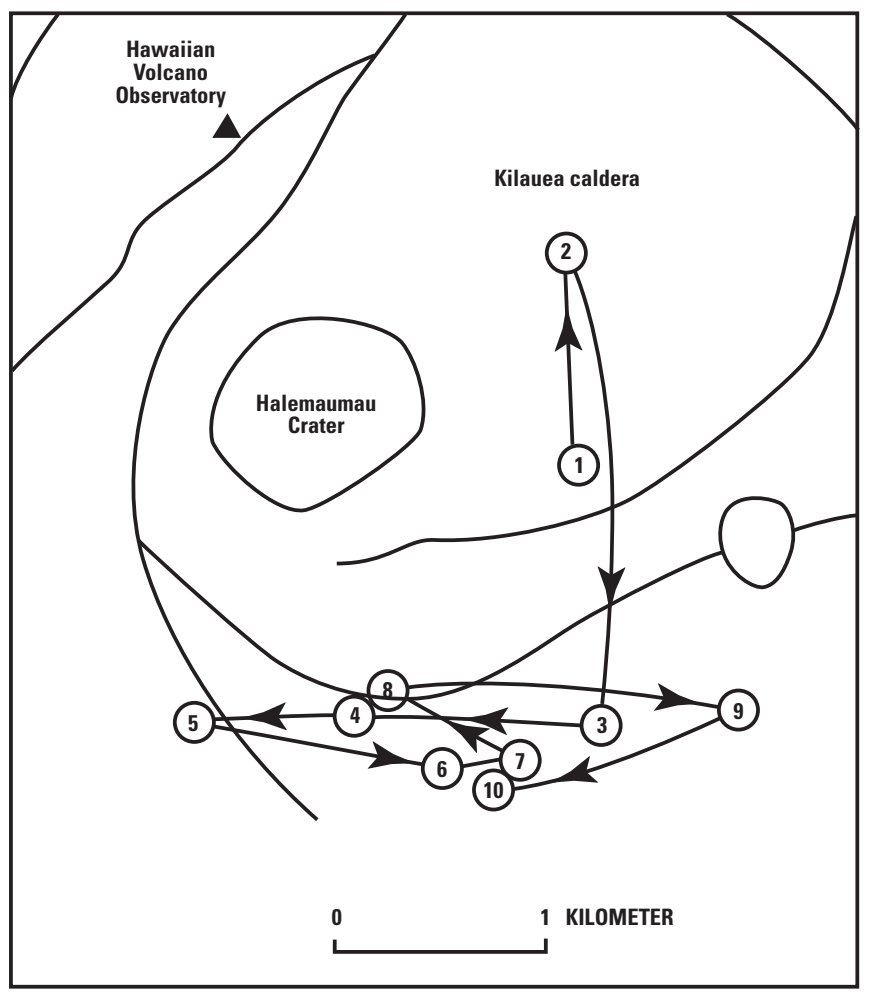

Figure 5. Lateral shift of the apex of uplift of inflating bulge on the summit of Kilauea as measured by ten level surveys from January 1966 to October 1967 (from Fiske and Kinoshita, 1969).
Triangulation surveys of the lower ERZ of Kîlauea were made in 1914 and expanded in 1933. Wingate (1933) mentions "uncertainties" in the 1914 data but does not give a comparison of the two surveys. A major eruption in Kîlauea's lower ERZ in 1955 was followed by new level and triangulation surveys to determine related geodetic changes (Karren, 1959; Lloyd, 1964). No eruption had occurred in the subaerial lower ERZ since 1840, although earthquakes, fault scarps and a graben in that area accompanied the withdrawal of lava and explosive eruptions of Halema'uma'u Crater in 1924. The several linear outbreaks of lava in 1955 occurred in the same general area as the lower ERZ displacements of 1924. The vents were related to $0.3-1.5 \mathrm{~m}$ of sinking of grabens along the rift zone. Horizontal widening between measured points on the surface across the eruptive zones was as much as $1.5 \mathrm{~m}$ normal to the fissures. Leveling at the summit of Killauea showed subsidence of as much as $0.4 \mathrm{~m}$, and its pattern indicated a volume close to the 108 million $\mathrm{m} 3$ of lava that erupted more than $40 \mathrm{~km}$ to the east. (Macdonald and Eaton, 1955; 1964).

While it was previously inferred that magma moved into Kīlauea's rift zones during summit collapses, deformation changes related to the 1955 lower east-rift eruption proved this relationship. Widening of the rift zone to accommodate dike intrusion was also quantitatively established.

Another major lower east-rift eruption occurred in 1960 near Kapoho. Again, deformation measured by leveling at Kîlauea's summit showed major subsidence related to the eruption (Richter and others, 1970).

Leveling surveys designed to detect geodetic changes on Mauna Loa began in 1964 (Decker and Wright, 1968). Precise leveling of a triangular route with legs approximately $2-\mathrm{km}$ long was established on the north summit region of Mauna Loa in 1964. A repeated level survey in 1965 showed several millimeters of uplift, only slightly above the expected error. A new leveling route along the southeastern rim of the caldera was established in the mid-1970s. It measured significant uplift before the 1984 eruption and renewed inflation following the eruption.

In 1975 a M7.2 earthquake occurred beneath the south flank of Kīlauea. Major vertical and horizontal geodetic changes were caused by this earthquake, the largest in Hawai' $i$ since 1868. Major ground-surface subsidence, as much as 3.5 m, took place at Halapē on the seacoast south of Kîlauea's summit and resulted in the drowning of a grove of coconut trees. The caldera area also subsided more than $1 \mathrm{~m}$ (Lipman and others, 1985.)

Yearly level surveys of Kīlauea's summit region have continued, and the surveys provide useful information sbout the Pu'u ' $\bar{O}$ 'o eruption. Long-term subsidence of 6-8 $\mathrm{cm} / \mathrm{yr}$ of the area near the benchmark SPIT, southwest of Halema uma u Crater, occurred during the first 20 years of the ongoing eruption. Cervelli and Miklius (2003) used the level data in conjunction with borehole-tiltmeter data to outline two distinct summit magma reservoirs - one centered $3.5 \mathrm{~km}$ below ground near SPIT, and a shallower reservoir about 0.5 $\mathrm{km}$ east of Halema uma u Crater, centered 500-700 m below 
ground level. The deeper reservoir is the source of long term subsidence of Kīlauea's summit, and between 1983 and 2002, it had lost a magma volume of about 2 percent of the eruption volume output of Pu'u 'Ō'ō.

\section{Tilt Measurements-1913-2006}

\section{"Summit tilt was so large from the Kapoho erup- tion in 1960 that a marble would have rolled across the Observatory floor.” Jerry Eaton}

Geodetic tilt is the change in angular relation between a portion of the Earth's surface and a horizontal plane. Small tilts can be measured in arc seconds or microradians. A surface that is bulging or subsiding causes tilting of the ground, either outward from the crest of a bulge or inward toward the bottom of a sag, respectively. For an area of concentric bulging or sagging, there is no tilt at the apex or bottom, and maximum tilt occurs roughly halfway between the apex and the edge of the deformed area.

Tilt measurements in Hawai' i started in 1913, when T. A. Jaggar installed horizontal pendulum seismographs (N-S and E-W) at Whitney Vault, $3.5 \mathrm{~km}$ northeast of Halema uma u Crater (Finch, 1925). The vault tilts in response to deformation centered near the crater. The rest position of a horizontal-pendulum seismograph moves if its base shifts, like a swinging gate whose rest position will change if the supporting gate post is tilted. Likewise, a drift in the rest position of a horizontal pendulum seismograph represents a component of tilt. Thus, the Hawaiian Volcano Observatory itself, first located near the present site of the Volcano House Hotel, inadvertently began to record tilt continuously. The data extend from 1913 to 1963.

Daily- and seasonal-temperature changes, rainfall events, and offsets caused by larger earthquakes, make these raw tilt records hard to decipher. Nevertheless, the large northward tilt of about 240 microradians in 1918 and 1919, and the southeastward tilt of 70 arc seconds in 1924, plotted by Waesche $(1940 ; 1942)$, clearly show the uplift and subsidence related to the buildup and withdrawal of the lava lake in Halema uma 'u Crater. Waesche's tilt-path diagram uses both the N-S and E-W tilt components recorded by the horizontal seismographs at the Whitney Vault. Waesche's diagram traces the magnified virtual path of the tip of a near-vertical rod perpendicular to the tilting surface, and it incorporates both tilt directions and time intervals. Powers $(1946 ; 1947)$ computed a method to remove the seasonal variations in the Whitney Vault records.

Much of the difficulty with horizontal-pendulum tilt measurements results from the short base on which the seismometers rest. Local tilting of the pier from temperature and local load changes, such as rainfall, can obscure the measurement of surface deformations over larger areas. Eaton (1959) solved this problem by developing long-base, water-tube tiltmeters. In these instruments a water tube connects containers in which a micrometer measures the water-level surface. The distance between the containers, which are either permanently or tem- porarily fastened on sturdy piers, can be many meters long. In 1956, Eaton established permanent N-S and E-W water tubes in the Uwēkahuna Vault that are still measured today (fig. 6), and he devised a network of piers for portable water-tube measurements in and around Kîlauea's caldera. Even if an individual pier of a long-base tiltmeter undergoes slight rotation caused by local stresses, such as temperature differences on the sides of the pier, the rotation does not significantly affect the long-base tilt between the piers.

The piers on which the water containers are mounted must be close to the same level; there needs to be an air line connecting the tops of the containers to eliminate pressure effects from wind and temperature, and the water line in the portable arrays needs to be flushed out to eliminate air bubbles in the water. Setting up and reading the arrays was done at night to minimize the temperature problem; the micrometers were close to ground level, and reading the water levels required lying on the ground, which was wet from flushing

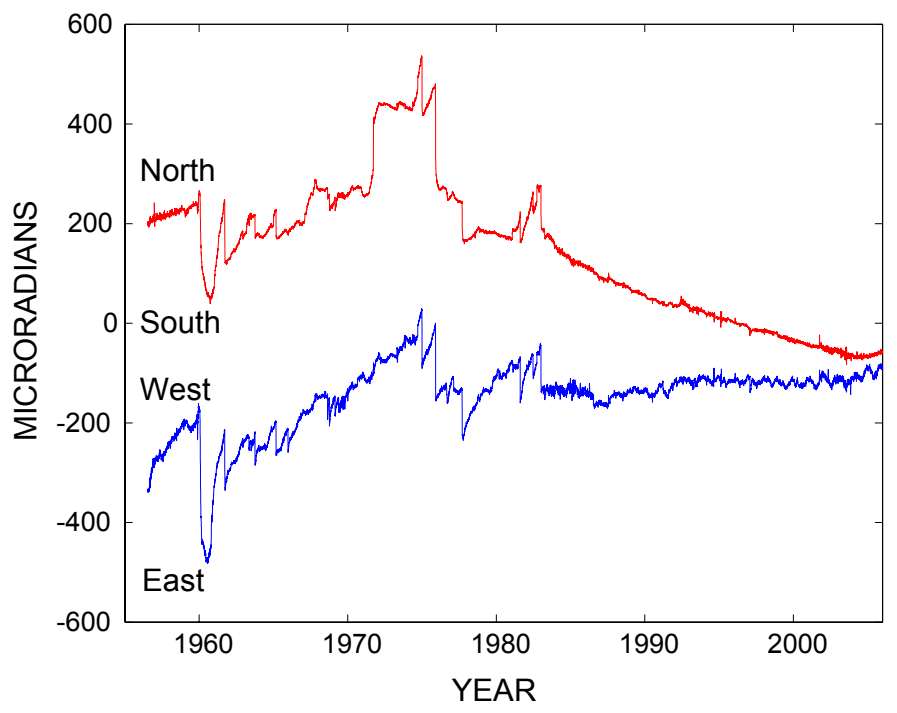

Figure 6. North-south and west-east tilt from 1956 through 2005 at the Uwēkahuna water-tube tiltmeter. Because the tiltmeter is located northwest of the common sources of inflation-deflation at Kilauea, northwestward tilts indicate inflation, while southeastward tilts represent deflation, although some offsets are associated with large earthquakes (for example, the 1975 earthquake on Kilauea's south flank). A large offset associated with the November 1983 Ka'oiki earthquake has been taken out of the time series, as the vault that houses the tiltmeters was damaged by the shaking; thus, the true tilt change over the earthquake is unknown. 
the water lines. Eaton's technique was soon dubbed "wet tilt." Vectors of tilt plotted from these long-base measurements clearly showed the inflation of Killauea Caldera prior to the Kîlauea Iki eruption in 1959 and the major subsidence related to the east rift eruption at Kapoho in 1960.

A rescue from "wet tilt" was adopted from a long-base leveling technique developed in Iceland by Eysted Tryggvason in the early 1960s. Tryggvason measured the changing relative displacements of three or more benchmarks about 50-meters apart by using an invar rod and a precise optical level. Dallas Jackson and Willie Kinoshita of HVO refined this technique by using three invar rods set up on benchmarks arranged in a triangle and measuring to them with a precise optical level shaded with a large umbrella set up near the center of the triangle (Yamashita, 1981). Level closure can be checked in the field by remeasuring the first benchmark. This technique was first used at HVO in 1969. It is done standing at the level gun during daylight, and soon became known as "dry tilt." Precision of "wet tilt" is about 0.3 microradians, and precision of "dry tilt" about 1.0 microradian (Okamura, 1975). However, comparison of different observers reading the permanent water-tube tiltmeters is about 5 microradians, and the uncertainty of duplicate setups of dry tilt is about 8 microradians. Since tilts between remeasurements at Kîlauea are often tens of microradians, "dry tilt," more formally known as "spiritlevel tilt," quickly replaced the portable water-tube technique and is still used on Kīlauea and Mauna Loa (Okamura, 1988).
Dvorak and Dzurisin (1997) summarized worldwide data and interpretations from volcano geodesy, including many studies on Mauna Loa and Kīlauea. Dvorak and Dzurisin show long-term comparisons of Kīlauea summit data (1920-1990) from elevation changes at SPIT benchmark, tilt from drift of the long-period seismometers at Whitney Vault, and the watertube tiltmeter at Uwēkahuna Vault (fig. 7).

A continuously recording mercury-capacitance tiltmeter, installed in the Uwēkahuna Vault in 1966, provided the first reliable continuous tilt monitoring at HVO; however, it had to be recalibrated with the water-tube tiltmeters from time to time. Electronic tiltmeters at the summit and along the ERZ tracked the initial dike propagation at the start of the Pu 'u 'Ō'o eruption (Okamura and others, 1988). Tilt cycles at the summit of Killauea related to the intermittent fountaining eruptions in the first years of the Pu 'u ' $\bar{O}^{\prime} \bar{o}$ eruption were recorded clearly by continuously recording tiltmeters (Wolfe and others, 1987).

Although continuously recording borehole tiltmeters have only a short base, boreholes drilled at least 3-m deep provide a sturdy foundation that minimizes the local tilt effects caused by temperature and weather. HVO presently has 12 borehole tiltmeters on Kīlauea and 6 borehole tiltmeters on Mauna Loa that transmit data to the observatory in near-real-time. The tiltmeters are most useful for detecting and tracking episodic magma movements beneath the volcanoes (Okamura and others, 1988; Cervelli and Miklius, 2003).

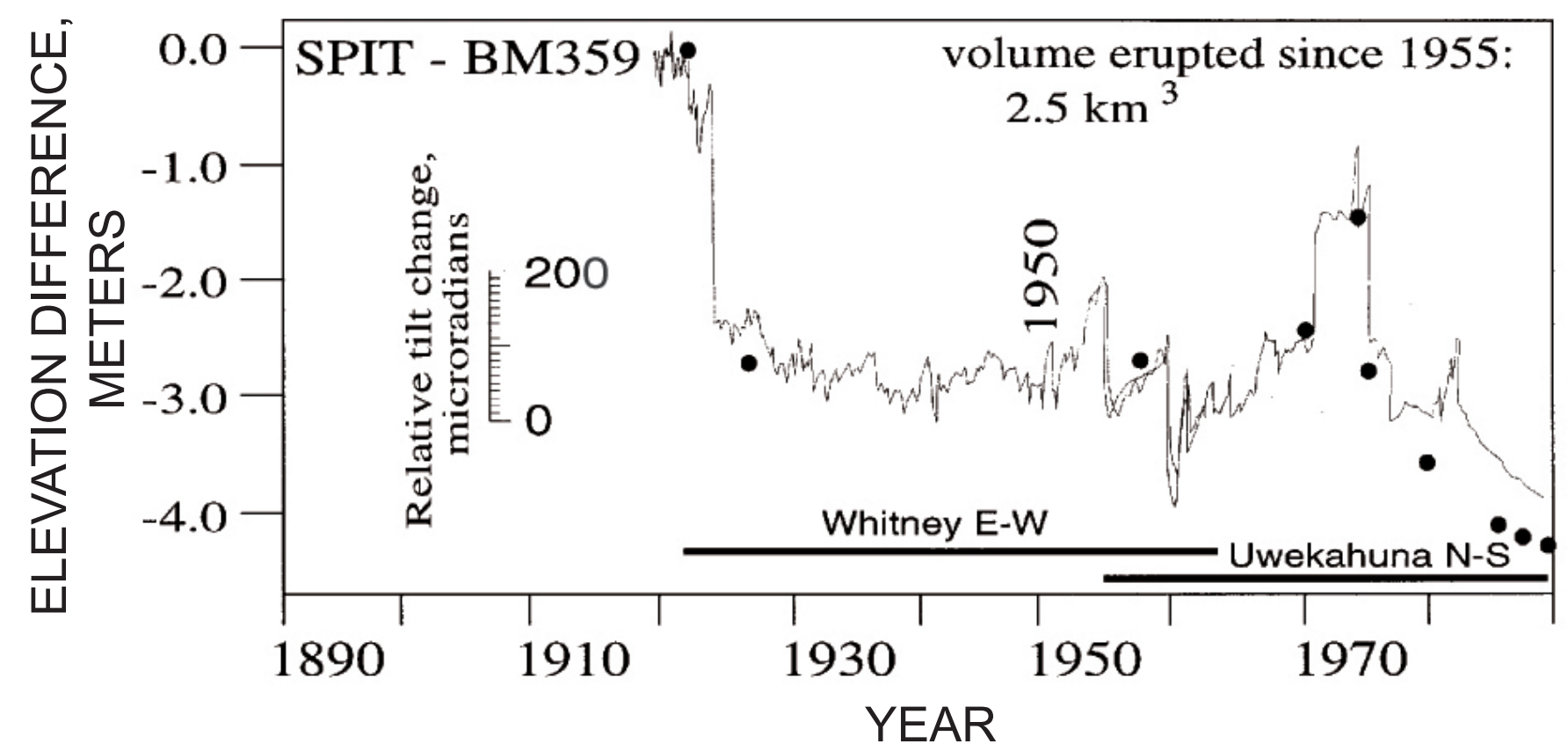

Figure 7. Comparison of elevation changes of the summit area of Killauea Volcano by leveling (black dots) and tilt changes at Whitney Vault on the north rim of the caldera and Uwē-kahuna Vault on the west rim of the caldera (Dvorak and Dzurizin, 1997). 


\section{Gravity Measurements- 1959-2006}

“F = MA.’' Isaac Newton, 1687

In 1840-41, Lieutenant Charles Wilkes (1845) led an elaborate expedition to the summit of Mauna Loa, one purpose of which was to determ ine the acceleration of gravity near Mauna Loa's summit. Wilkes was commander of the U.S. Navy's exploring expedition to the South Seas. His flagship entered Hilo Bay on December 9 1840, and with the essential help of Dr. Gerrit Judd, a medical missionary from Honolulu, Wilkes built a stone and tent encampment on the east rim of Mauna Loa's caldera at a location he named Pendulum Peak because it housed the pendulum apparatus he used to measure gravity. The expedition was a classic military endeavor. Wilkes and his men spent 28 days on Mauna Loa, and the effort involved 275 Hawaiian porters and 50 sailors from the ship. The ascent took 6 days, and 20 days were spent near the summit. Snow and windstorms, severe cold, and altitude sickness plagued the expedition; they even established a hospital in a lava tube at $9,745 \mathrm{ft}$. It is not clear whether or not the gravity measurement was successful since the result is not mentioned in Wilkes' voluminous report.

During 1959-60, 119 years after the Wilkes expedition, Harold Krivoy was conducting a gravity survey of the Island of Hawai $i$ when the Kîlauea Iki-Kapoho eruption occurred (Krivoy and Eaton, 1961; Richter and others, 1970). Krivoy noticed that repeat gravity measurements with a portable spring-balance gravimeter in the summit area of Kilauea increased as the summit subsided. Radial tilt at Uwēkahuna during that subsidence episode exceeded 300 microradians, but no quantitative elevation changes for the gravity benchmarks were measured. It was assumed that changes in gravity might occur with elevation changes - the theoretical free-air gravity gradient is -3.086 microgals $/ \mathrm{cm}$ - but this was the first confirmation of that effect on Killauea. However, since the elevation decreases were not known, the free-air changes could not be removed, and any more subtle changes related to possible mass changes from the subsidence could not be determined.

The M7.2 earthquake on November 291975 beneath Kīlauea's south flank caused major summit subsidence and rift-zone extension on Kīlauea (Tilling, 1976; Lipman and others, 1985). By coincidence, a precise gravity survey performed to accompany a new first order level line from Hilo to the summit of Mauna Loa had just been completed only six days before the earthquake. This gravity survey included measurements on 17 benchmarks in the summit area of Kilauea that were (and still are) measured by leveling to determine their elevation changes (Kinoshita and others, 1974). For the area of summit subsidence, Jachens and Eaton (1980) measured a systematic gravity change averaging -1.71 microgals $/ \mathrm{cm}$ (1.38 microgals/cm after correcting for the free-air effect). The maximum gravity change was $234+/-7$ microgals at benchmark HVO 36, $1 \mathrm{~km}$ southeast of Halema uma u Crater, which subsided $135 \mathrm{~cm}$. Jachens and Eaton concluded that the systematic gravity changes indicated that the volume of magma withdrawn from beneath Kīlauea's summit exceeded the volume of collapse.

From December 1975 to April 1977, Dzurisin and others (1980) continued to measure the microgravity and elevation changes in the summit area of Killauea following the M 7.2 earthquake. Although as much as $180 \mathrm{~mm}$ of subsidence continued, the ratio of gravity change to elevation change reversed sign to -2.94 microgals/cm corrected for the free-air effect. Dzurisin and others (1980) interpreted this reversal as continuing extension accompanied by magma refilling some of the subsurface space created by the initial earthquake subsidence and extension. In other words the volume of magma beneath the summit area increased despite the continuing subsidence.

Johnson $(1987,1992)$ examined the role of the bulk modulus of magma under changing pressure in shallow reservoirs and the shear modulus of the host edifice, and he concluded that some of the complex relationships of magma volume changes to surface uplift and subsidence require an edifice shear modulus that is about 2 times the value of the magma bulk modulus. In other words, microgravity changes caused by changes in magma volume and pressure are complex and cannot be used as a simple proxy for surface-elevation changes. On the other hand, measurement of both elevation and microgravity changes can provide important insights into the dynamics of subsurface magma movement and surface deformations.

This conclusion is amply demonstrated by Kauahikaua and Miklius (2003), who demonstrated that the withdrawal of magma from the summit of Kilauea during the first 20 years of the Pu 'u 'O' 'o-Kupaianaha eruption was complex (fig. 8). The long-term trend of deformation of the summit of Killauea during the eruption was persistent subsidence, totaling $1.3 \mathrm{~m}$ from 1983 to 2003. By combining microgravity changes and elevation changes at the summit, periods of magma withdrawal and replenishment became evident. Overall, Kauahikaua and Miklius (2003) found that, during the course of the eruption, magma supply to the summit reservoirs was only slightly lower than the volume erupted.

\section{Electronic Distance Measurements-1964-2006}

\section{Measuring millimeters with the speed of light}

Electronic Distance Measurement, known colloquially as EDM, began at HVO in 1964 on a 3,098 $\mathrm{m}$ line across Kīlauea's caldera from Uwēkahuna to Keanakāko `i (Decker and others, 1966). Both a "Tellurometer" that used radiofrequency signals, and a "Geodimeter" that used a tungsten- 
bulb light were used in the first experiments. The Geodimeter proved more stable with a standard deviation of $\pm 1.1 \mathrm{~cm}(3.6$ ppm). Because the light signal was weak, the measurements had to be made at night.

Uplift and outward tilt of the summit area of Kîlauea began following the October 5-6, 1963, eruption near Nāpau Crater on Kīlauea's middle ERZ. Slow and persistent uplift continued until March 5-15, 1965, when rapid summit subsidence and inward tilt accompanied a 29-million-m3 eruption near Nāpau and Makaopuhi Craters. Both maximum uplift and subsidence of the summit amounted to $25 \mathrm{~cm}$. During the interval of October 22, 1964, to March 1, 1965, the EDM line across the caldera lengthened by $12 \mathrm{~cm}$, and between March
1 and 8, 1965, the EDM line shortened by $28 \mathrm{~cm}$. This close correlation among leveling, tilt, and EDM helped to support an elastic model of Kîlauea's summit deformation (Decker and others, 1966). EDM also proved fast and inexpensive compared to leveling.

EDM across the 2.5-km-diameter (NW-SE) of Mauna Loa's caldera began in 1965 (Decker and Wright, 1968) with a reproducibility of $10 \mathrm{~mm}$ (4 ppm). Extension across the caldera and increasing shallow earthquakes occurred prior to both the 1975 and 1984 eruptions of Mauna Loa (Lockwood and others, 1987). Figure 9 shows the changes in distances across the caldera diameter from 1965 through 2005.

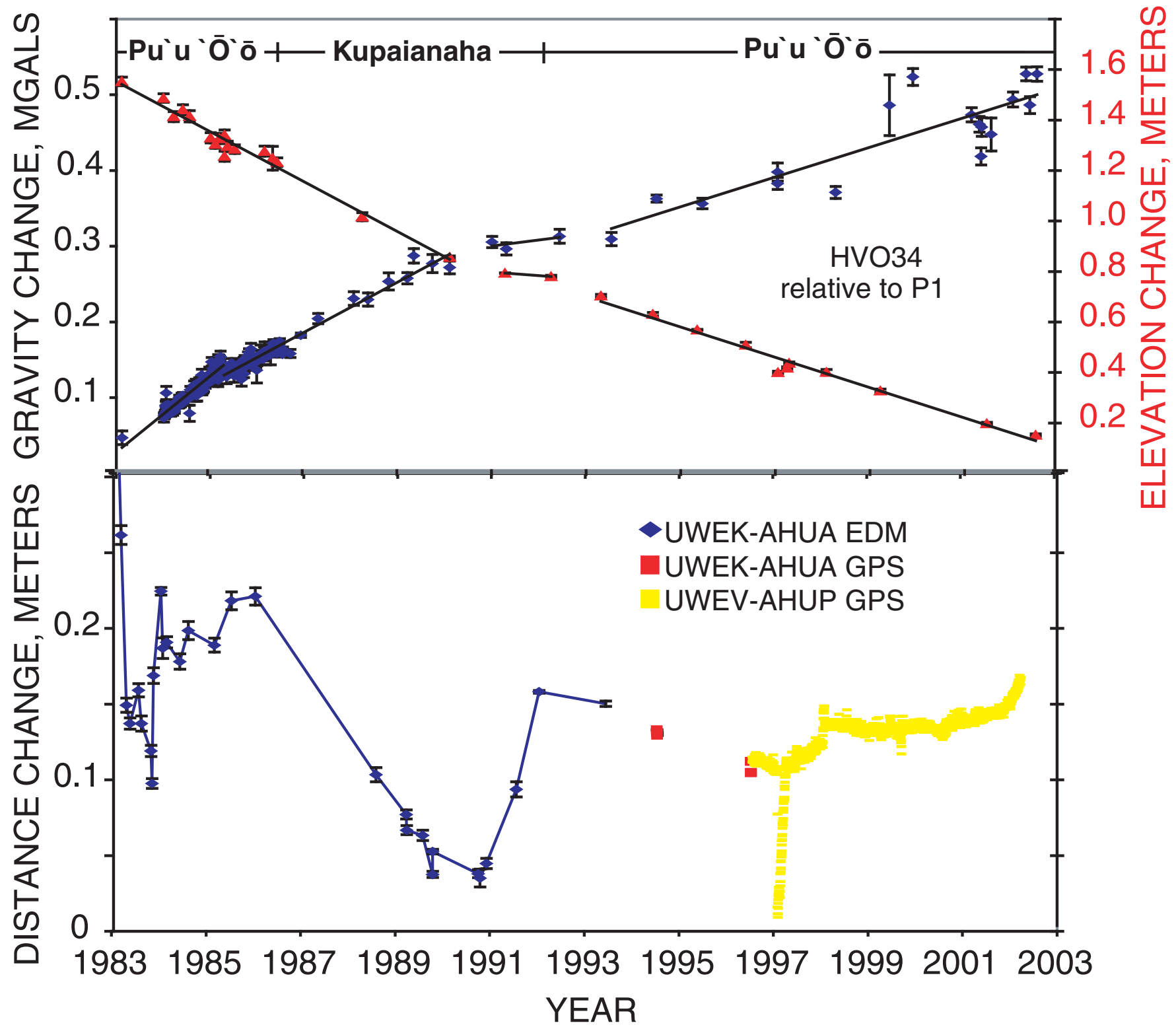

Figure 8. Gravity changes (blue) versus elevation changes (red) during the Pu`u 'Ō`ō-Kupaianaha eruption (top), along with changes in distance across Killauea's caldera (bottom; Kauahikaua and Miklius, 2003). 
One of the significant results of the deformation measurements on Mauna Loa from leveling, tilt, and EDM data was their good fit to elastic-deformation models that yielded depths to the top of a magma chamber of 3-4 km. These results provided additional evidence that as Hawaiian volcanoes grow higher, so do their magma chambers (Decker and others, 1983).

Another major benefit of EDM is that it can be used to do trilateration, in which the distances of three sides of a triangle are measured, rather than by using a base-line and horizontal angles as in triangulation. Trilateration greatly improves the accuracy of determining horizontal geodetic changes. HVO began using this technique in the late 1960s with a Model 8 Geodimeter that could measure lines many kilometers long in daylight. Analysis of triangulation surveys done on Kîlauea in 1896, 1914, 1949, 1958, and 1961, suggested that the south flank of Kîlauea was being displaced seaward, and the trilateration measurements confirmed this movement. These surveys (Swanson and others, 1976) indicated a maximum of $4.5 \mathrm{~m}$ of displacement of the south flank between 1914 and 1971 in a direction perpendicular to the rift system of Kîlauea. Swanson and others (1976) hypothesized that forceful injection of

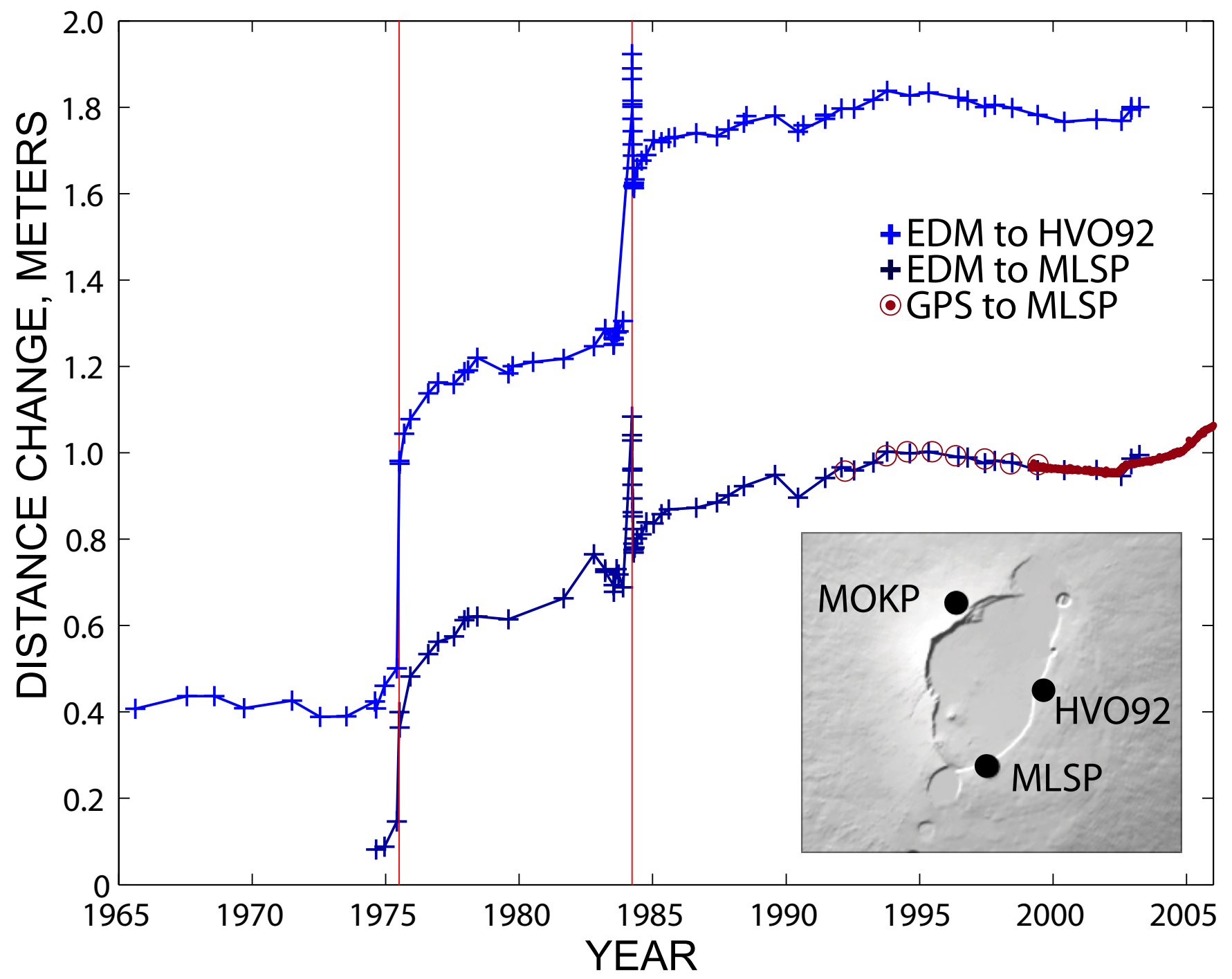

Figure 9. Extension of Mauna Loa's caldera before, during, and after the1975 and 1984 eruptions as measured by EDM, and later by GPS, along lines between benchmarks MOKP and HVO92, and MOKP and MLSP (approximately perpendicular to the eruption fractures). The increases in line length of about $50 \mathrm{~cm}$ in 1975 and $65 \mathrm{~cm}$ in 1984 result from the dike intrusions that fed the eruptions. The decrease of $30 \mathrm{~cm}$ during the 2 weeks of the ongoing 1984 eruption was caused by the transfer of at least 220 million $\mathrm{m}^{3}$ of magma from beneath the summit into the volcano's northeast rift zone (Lockwood and others, 1987.) 
magma into the rift zones caused this displacement; they also suggested that the accumulating strain in the south flank of Kîlauea might lead to a major earthquake in that region. Their conclusion was written in 1974, fifteen months before the major $\mathrm{M}=7.2$ Kîlauea earthquake, but was not published until 1976.

Large horizontal displacements of the south flank of Kîlauea Volcano were caused by the $1975 \mathrm{M}=7.2$ earthquake (Tilling, 1976; Lipman and others, 1985). Focal-mechanism determinations and the pattern of aftershocks of this earthquake indicate seaward displacement of an upper block along gently dipping fault planes at depths of 6-10 km. Figure 10 shows the vector displacements of the ground surface measured by trilateration surveys between 1974 and 1976. The profound structural and dynamic changes caused by this earthquake brought about a "regime change" in the behavior of Kîlauea Volcano. Scientists at HVO often refer to the differences in character of seismicity, geodetic changes, magma supply, eruptions, and other manifestations of Hawaiian volcanism as "before" and "after" the 1975 earthquake.

Major changes in length along EDM lines across the south flank of Killauea Volcano have been measured since 1965. A 5.4-km-long line from the near the top of Hōlei Pali to the sea contracted $34 \mathrm{~cm}$ between 1965 and 1970 (Swanson and others, 1976, fig. 10) after which flows from the Mauna Ulu eruption prevented further measurements. Another EDM line farther west across the Hilina fault system (fig. 11) showed continued contraction of $30 \mathrm{~cm}$ between 1970 and

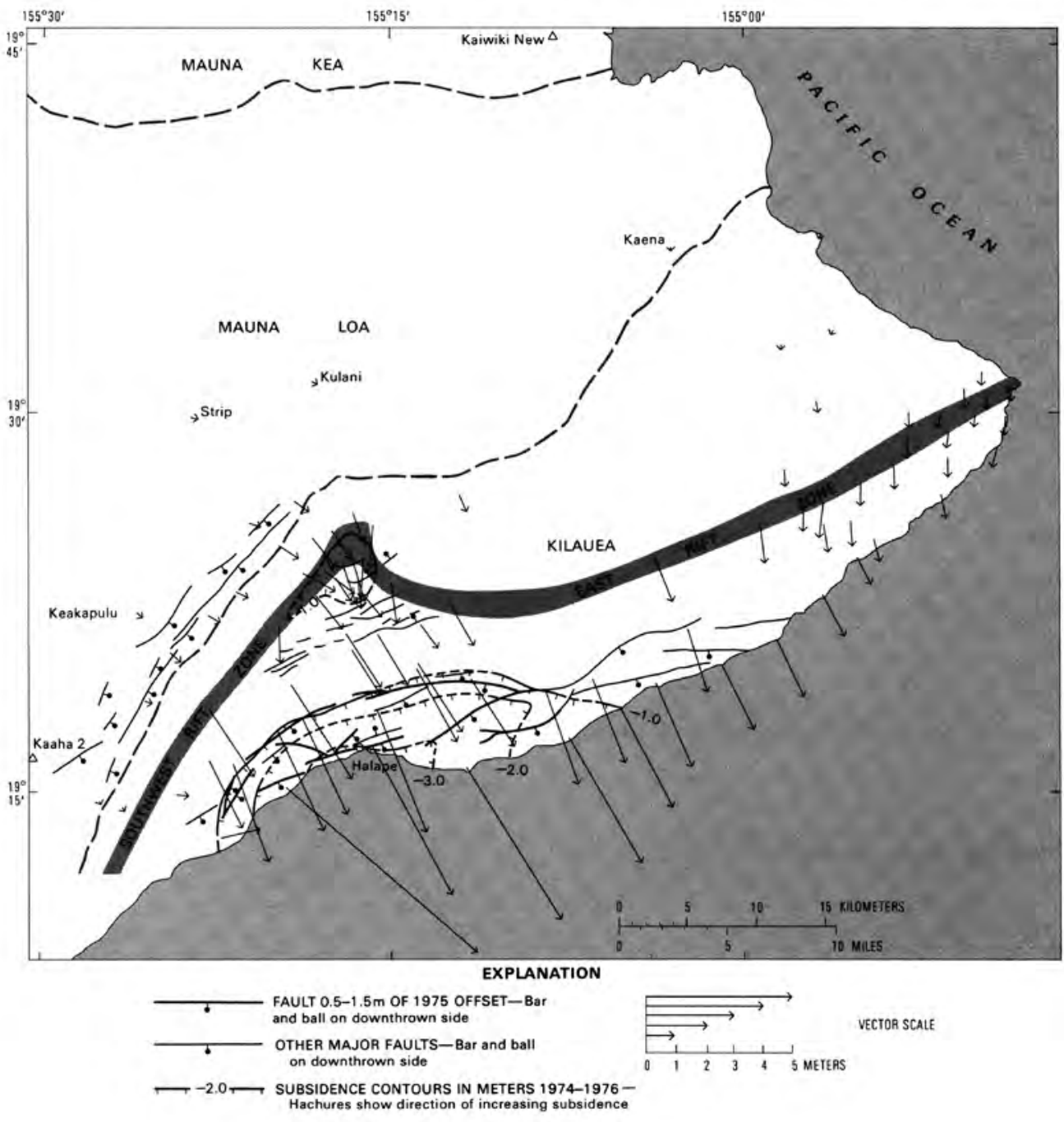

Figure 10. Displacements on Kilauea Volcano related to the $1975 \mathrm{M}=7.2$ earthquake (from Lipman and others, 1985, fig. 13). Horizontal displacements (note the scale is in meters) are inferred from trilateration measurements made from fall 1974 to spring 1976. The largest subsidence contours are shown near the south coast of Kïlauea near Halapē. 
1975 before the $M=7.2$ earthquake caused a great extension of the line by $3.4 \mathrm{~m}$.

In both figures 9 and 11, Global Positioning System (GPS) measurements - at first intermittent and more recently continuous - have replaced EDM measurements. This is the ongoing story of the evolution of techniques used to measure geodetic changes.

\section{Global Positioning System (GPS)-1987 to 2006}

\section{“...one giant leap for mankind.” Neil Armstrong, 1969}

Development and deployment of multiple satellites to locate geographic positions on Earth accurately has led to major improvements in geodetic monitoring of volcanoes. Commercial GPS devices have been rapidly developed, from hand-held units to more complex signal receivers and decoders that can be accurately placed over benchmarks. Both surveying and navigation have been improved significantly by using GPS.

GPS measurements began on Kîlauea and Mauna Loa Volcanoes in 1987 (Dvorak and others, 1989). The technique of measuring several locations with GPS and repeating these

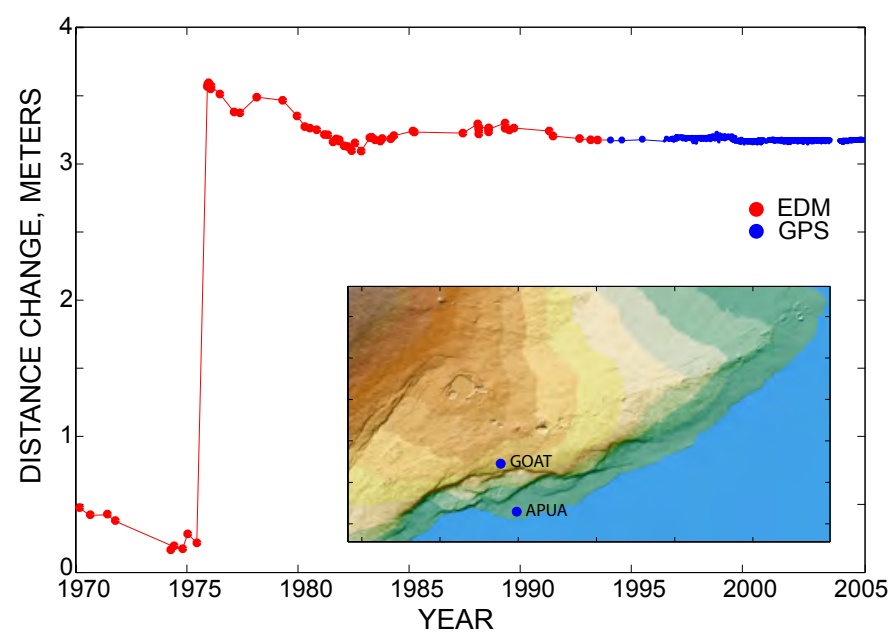

Figure 11. Changes in distance across the south flank of Kilauea Volcano since 1970 as measured along a 8.6-kmlong line across the Hilina fault system to the sea between benchmarks Goat and Apua Point. Shortening of these lines indicates accumulating compressional strain in the south flank, and lengthening indicates relief of this compressional stress. Note the $3.4 \mathrm{~m}$ extension from the $1975 \mathrm{M}=7.2$ earthquake. Compression dominated again after the 1975 earthquake until 1983, the start of the Pu'u 'Ō'o eruption. Since then, the line has been relatively stable compared to the displacements from 1970 to1983. measurements at a later date provides a rapid method to determine both vertical and horizontal displacements.

One of the most interesting results of the early GPS surveys on Killauea was the confirmation that the south flank of Kilauea continued to move seaward after the 1975 earthquake (Owen and others, 2000). Details of the horizontal and vertical movements between 1990 and 1996 indicated that the south flank was moving up to $8 \mathrm{~cm}$ per year in a south-southeast direction, and that the summit and rift zones were subsiding at maximum rates of $8 \mathrm{~cm}$ per year. Elastic-dislocation modeling suggests that the active sources of this ongoing deformation involve deep rift openings below the ERZ, fault slip along a sub-horizontal fault (decollement) near the base of the volcano, and deflation near the summit caldera.

In 1996, continuous GPS measurements began in Hawai i. Several institutions working together have established more than 30 continuous GPS sites on Mauna Kea, Mauna Loa, and Kīlauea. These data provide unprecedented temporal detail of geodetic changes.

The continuous GPS network has recorded numerous events that provided further clues to the magmatic and tectonic processes at Mauna Loa and Kīlauea, including two episodes of dike opening, in 1997 (Owen and others, 2000; Segall and others, 2001) and 1999 (Cervelli and others, 2002a).

The temporally dense sampling of the continuously recording network also allowed the recognition of aseismic slip events on Kīlauea's south flank (Cervelli and others, 2002b; Brooks and others, 2006; Segall and others, 2006). These events are characterized by slip of up to $5 \mathrm{~cm}$ on coastal GPS sites over 1-2 days. The energy released by these events corresponds to moment magnitudes up to 5.8, but are accompanied by only micro-seismicity.

The continuous GPS network is ideal for tracking changes in the magmatic systems of Kîlauea and Mauna Loa. Using the cross-caldera line lengths as a proxy for inflation status, figures 12 and 13 illustrate the rapid and numerous changes at these volcanoes. At Kîlauea, the GPS network recorded the slow, steady deflation of the summit magma reservoir as slightly less magma was supplied than erupted at $\mathrm{Pu}{ }^{\prime}{ }^{\prime}{ }^{\circ}{ }^{\prime} ' \bar{o}$. There was a period of inflation in 2002 , during a time of decreased effusion at the eruption site, which ended with the opening of new vents on Pu'u 'Ō'ō cone, at the same time that Mauna Loa began reinflating (Miklius and Cervelli, 2003). In contrast, there was no appreciable decrease in effusion rates accompanying the inflation that started in late 2003.

One of the more closely watched graphs on the HVO website is the plot of the difference in horizontal positions of two continuous GPS stations on the caldera rim of Mauna Loa (fig. 13).The graph shows the abrupt change from contraction to extension across the caldera in 2002. The initially high inflation rates continued until October 2002 and then slowed until mid-2003. Inflation rates accelerated dramatically in mid-2004, best illustrated by the acceleration of extension of longer baselines from the northwest to southeast flanks. This acceleration coincided with the start of a swarm of very deep (30-50 km), long-period microearthquakes. The high rate of 


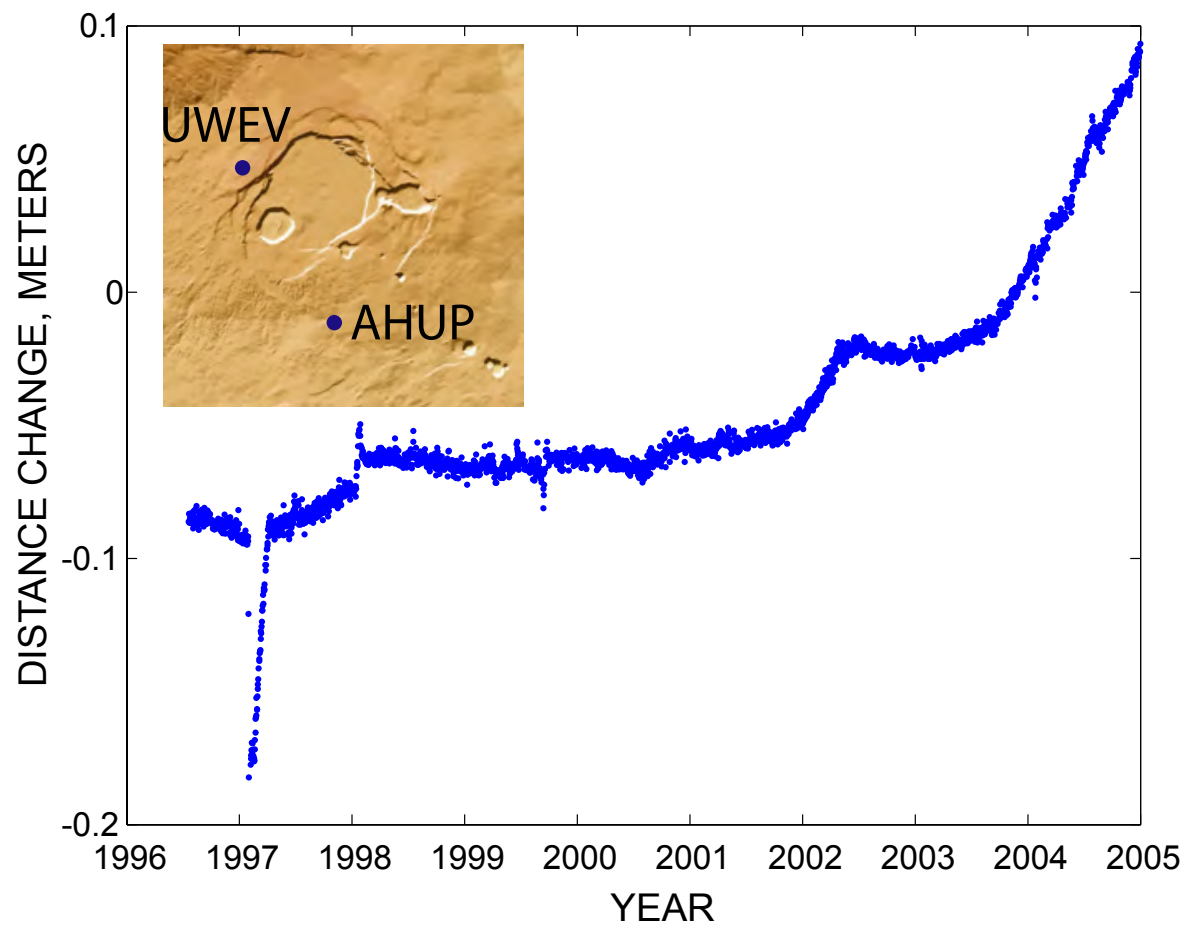

Figure 12. Line length change across Kïlauea's summit caldera from 1996 through 2005. Although changes are not as dramatic as those measured with EDM before the start of the Pu'u 'O' $\overline{0}-K u p a i a n a h a$ eruption, the continuous GPS measurements afford recognition of smaller events and correlation with other observations and data sets.

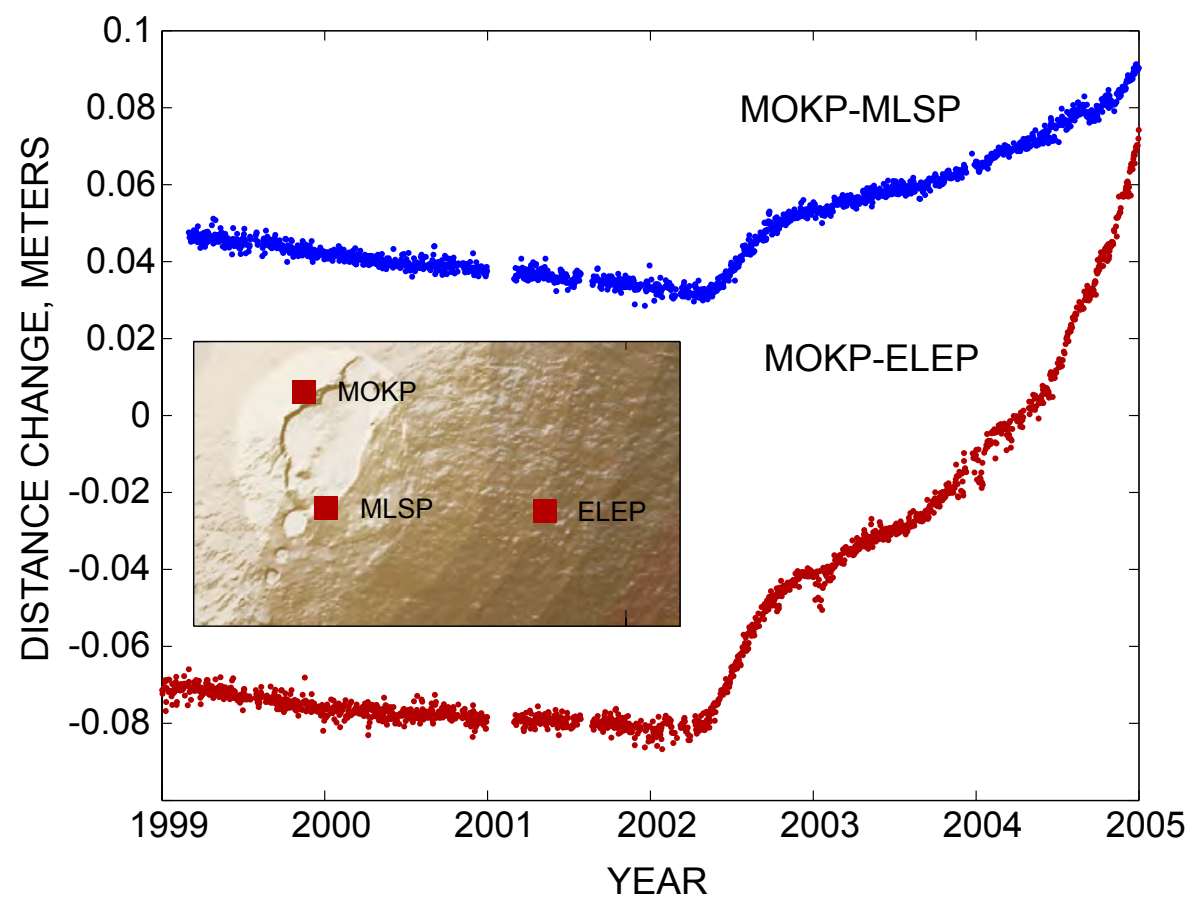

Figure 13. A rapid increase in distance across the summit caldera started in May 2002. Even faster rates of extension were observed across the flanks, reflecting the opening of a dike-like body beneath the summit caldera. 
inflation continued through 2005, though the deep seismicity abated at the end of 2004. Modeling of the GPS data suggests that, in addition to an inflating magma reservoir, the bulk of the deformation is due to opening of a dike in the summit region (HVO, unpub. data, 2004).

The combination of the dense temporal sampling of the continuous GPS network with the spatial density afforded by GPS surveying gives unprecedented detail of the deformation patterns on Hawaiian volcanoes (for example, fig. 14). The recent advances in the use of interferometric synthetic aperture radar (InSAR) augment this capability by enormously increasing the spatial density of deformation measurements.

\section{Satellite Radar Interferometry-1994-2006}

\section{“Space...the final frontier.” Captain James T. Kirk}

Interferometric Synthetic Aperture Radar (InSAR) is the most recent advancement in detecting deformation of the Earth's surface. InSAR uses two satellite-radar images of the same area on the ground acquired from an identical point in space at different times. Radar-range measurements, which contain information about the distance between the satellite and ground, from the earlier image are subtracted from the later to form an interferogram. After correction for orbital and topographic effects, the interferogram shows how much surface deformation occurred in the interval between the acquisition of the two images (Massonnet and Fiegl, 1998). Surface displacements as small as $1 \mathrm{~cm}$ can be identified in a single interferogram, and displacements of a few millimeters can be recognized in stacks of multiple interferograms (for example, Wright and others, 2001). Interferograms are, however, subject to distortion due to atmospheric artifacts, especially in tropical environments like Hawai'i where atmospheric anomalies can cause more than $10 \mathrm{~cm}$ of apparent deformation (Rosen and others, 1996). Further, variations in the characteristics of the surface between satellite passes, for example, due to ice, snow, or vegetation, cause the radar signal to break down in some areas, preventing a deformation measurement from being recovered. In Hawai' i, these "incoherent" areas are caused mostly by dense vegetation, especially on the windward side of the island (Rosen and others, 1996).

InSAR measures only surface displacement that occurs in the same direction as the radar's line-of-sight, which is usually inclined 15-45 degrees from vertical. An interferogram, therefore, contains a mix of horizontal and vertical deformation. Converting InSAR measurements into separate horizontal and vertical displacements, requires at least two interferograms that cover the same time period and image the ground from different points in space (for example, Wright and others, 2004; Yun and others, 2006).

The first radar observations of Hawai'i from space were used mostly for geologic analyses of surface characteristics
(Gaddis and others, 1989) and mapping of active lava flows (Zebker and others, 1996). The April and October 1994 Space Shuttle Imaging Radar-C (SIR-C) missions provided the first opportunity for InSAR measurements of Hawaiian volcanoes (Rosen and others, 1996). The result of that analysis indicated strong, atmospheric anomalies, but subsidence at Pu 'u 'Ō $\bar{o}$ was also detected during the six month period between Space Shuttle flights.

On completion of a downlink station at the University of Hawai' i in Mānoa in 1998, InSAR results were obtainable by using the European Space Agency (ESA) ERS-1 and -2 satellites. Data from ERS-2 were used to map surface displacements associated with the September 1999 upper ERZ dike intrusion at Kīlauea (Cervelli and others, 2002a). These InSAR results, together with GPS and leveling data, also suggested slip along the Kulanaokuaiki Pali, one of the faults of the Koa'e fault system, during the intrusion.

ESA's ENVISAT satellite, launched in 2002, has provided the greatest wealth of InSAR data for Hawai' $i$ due to the instrument's ability to view the island by using a variety of different look angles. As a result, radar images of the island are acquired almost every other day, allowing deformation of Kīlauea and Mauna Loa to be tracked in detail. This frequency of acquisitions proved especially useful for tracking inflation of the two volcanoes during 2003-06.

GPS results were used to detect the onset of inflation at Mauna Loa in mid-2002. Although ENVISAT data do not cover this period, results from 2003 to 2005 indicate a pattern of surface displacement consisting of two uplift lobes straddling the caldera, with greater uplift southeast of the caldera (fig. 15). This pattern is consistent with magma accumulation in both a focused region beneath the caldera and an elongated source that runs the length of the caldera (Amelung and others, 2007).

Deformation in the area of Kîlauea's caldera has been dominated by subsidence between 1983 and 2001 during the Pu'u 'Ō'o-Kupianaha eruption. Much of this deformation has been detected by annual leveling surveys, and the GPS network at the volcano's summit is relatively sparse (Cervelli and Miklius, 2003). During 2001-03, this subsidence changed to inflation, with ever-increasing rates of uplift. InSAR results from 2003 to 2005 have been instrumental in documenting the spatial characteristics of the summit inflation, including a translation in the center of uplift from near Halema 'ua 'u Crater to the south caldera (fig. 16). Continued application of InSAR to Hawaiian volcanoes offers the prospects of better understanding not only the characteristics of magmatic sources at depth, but also tectonic activity, magma-tectonic interactions, and processes associated with eruptive vents and active lava flows. 

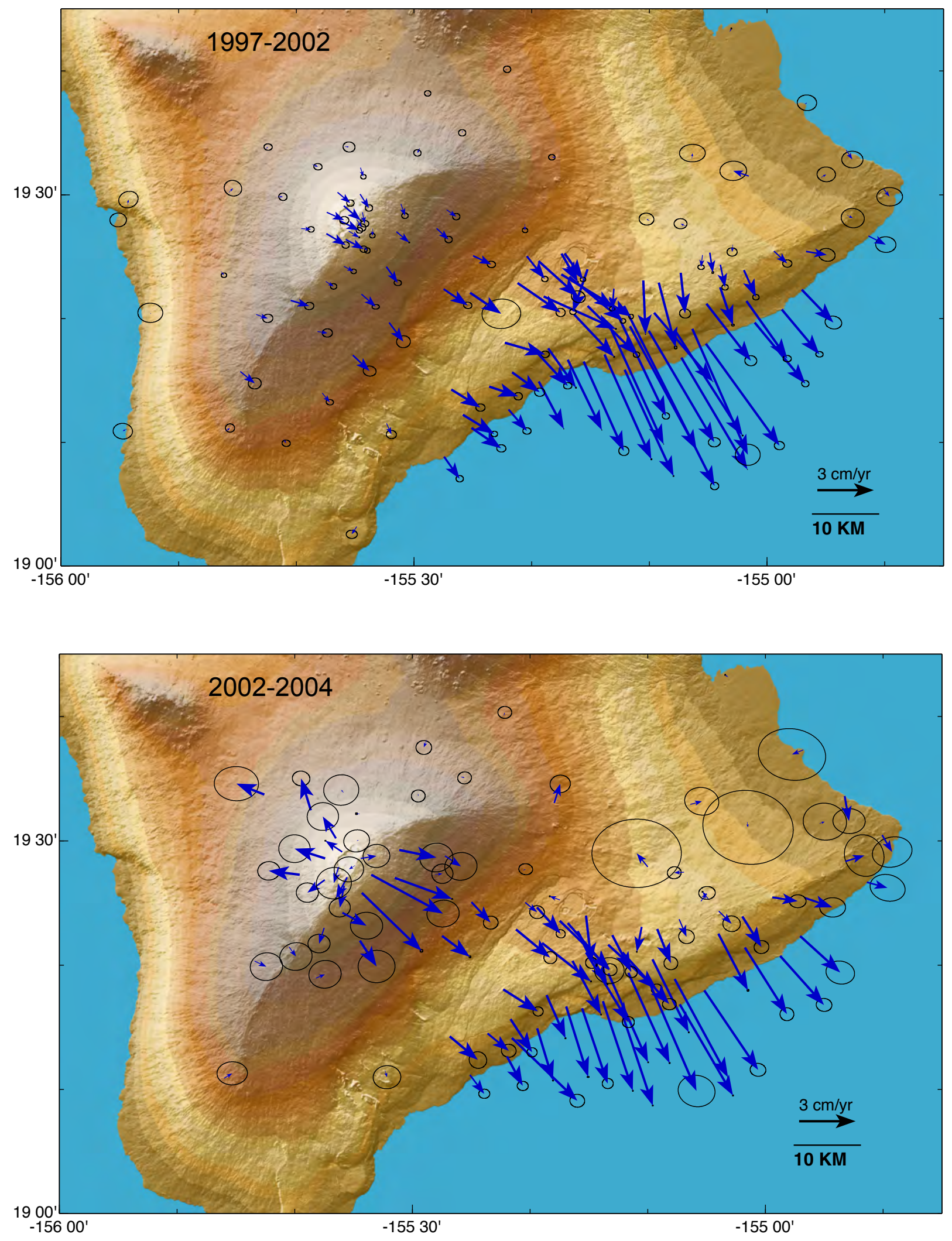

Figure 14. Horizontal velocities measured by both survey and continuous GPS measurements from 1997 to 2002, and from 2002 to 2004. Figure from Miklius and others (2005). 


\section{The Future of Volcano Geodesy in Hawaì i}

\section{"Somewhere, there is something incredible waiting to be known.” Carl Sagan}

The volcanoes of Hawai i, particularly Kīlauea, have served as a testing ground for new deformation monitoring techniques throughout the 20th century. Leveling surveys begun in 1912 and Thomas A. Jaggar's accidental discovery of ground tilt in 1913 were the first direct attempts to measure the changing shape of the ground surface in Hawai $i$ due to magmatic and tectonic activity. New technologies, including the clinometer, water-tube tiltmeter, and EDM, were developed or tested in Hawai i. Towards the end of the 20th century, Kîlauea was the site of some of the first successful applications of GPS and InSAR to volcanoes.

The next advances in volcano geodesy will probably build on existing methods. For example, C-band radar

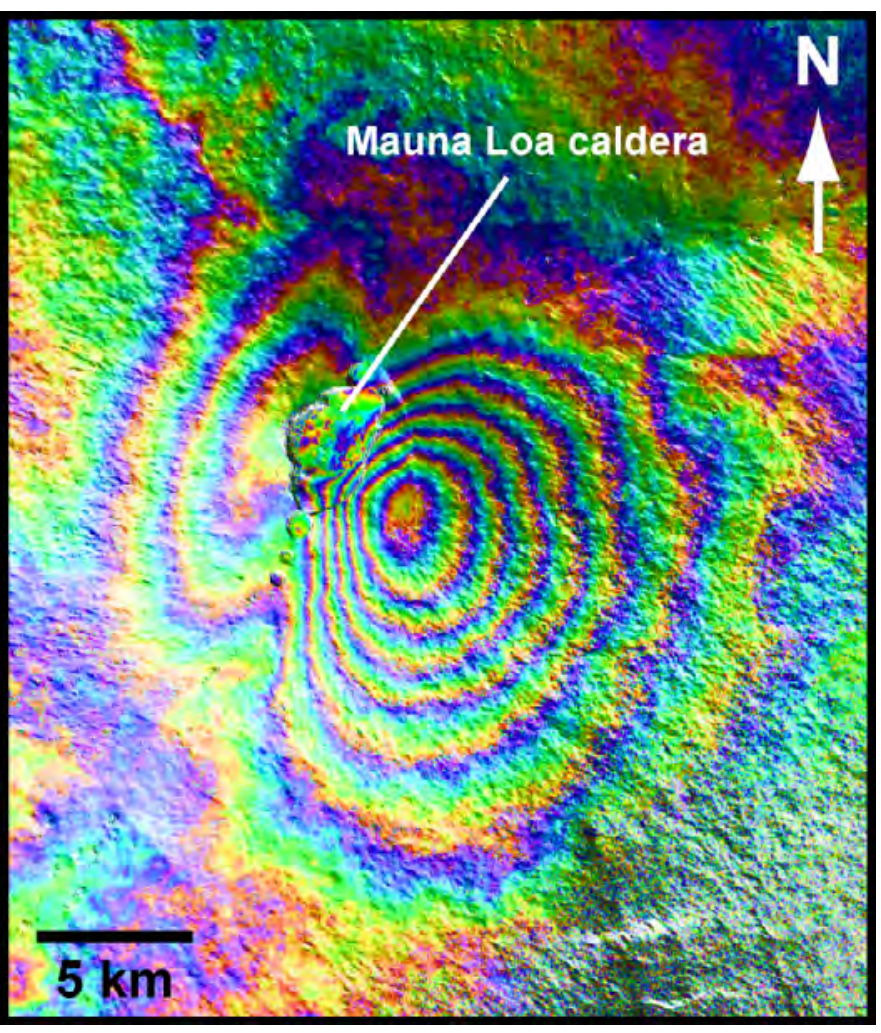

Figure 15. Interferogram made from ENVISAT images acquired on January 27, 2003, and June 20, 2005, showing deformation between those two time periods. Each cycle of color indicates $2.76 \mathrm{~cm}$ of line-of-sight displacement between the satellite and the ground. In this case, the two enclosed concentric ovals indicate uplift of Mauna Loa's summit area. interferograms are not coherent in areas of dense vegetation, including the rainforests of Hawai i. L-band radar data, however, can penetrate vegetation, and derived interferograms have the potential to provide an unprecedented level of spatial resolution of deformation, even compared to C-band interferograms (Lu and others, 2005). Signal processing techniques, like permanent and persistent scatterers, will also improve the spatial resolution of InSAR and help to mitigate errors caused by the atmopshere (Ferretti and others, 2001; Hooper and others, 2004). Applying these new methods and data types to Hawai' $i$ will surely result in discoveries of deformation where previous measurements (for example, EDM or GPS) had not been possible (due to, for example, dense foliage).

Another existing geodetic tool, GPS, is similarly evolving. Displacement data from GPS are now available at high

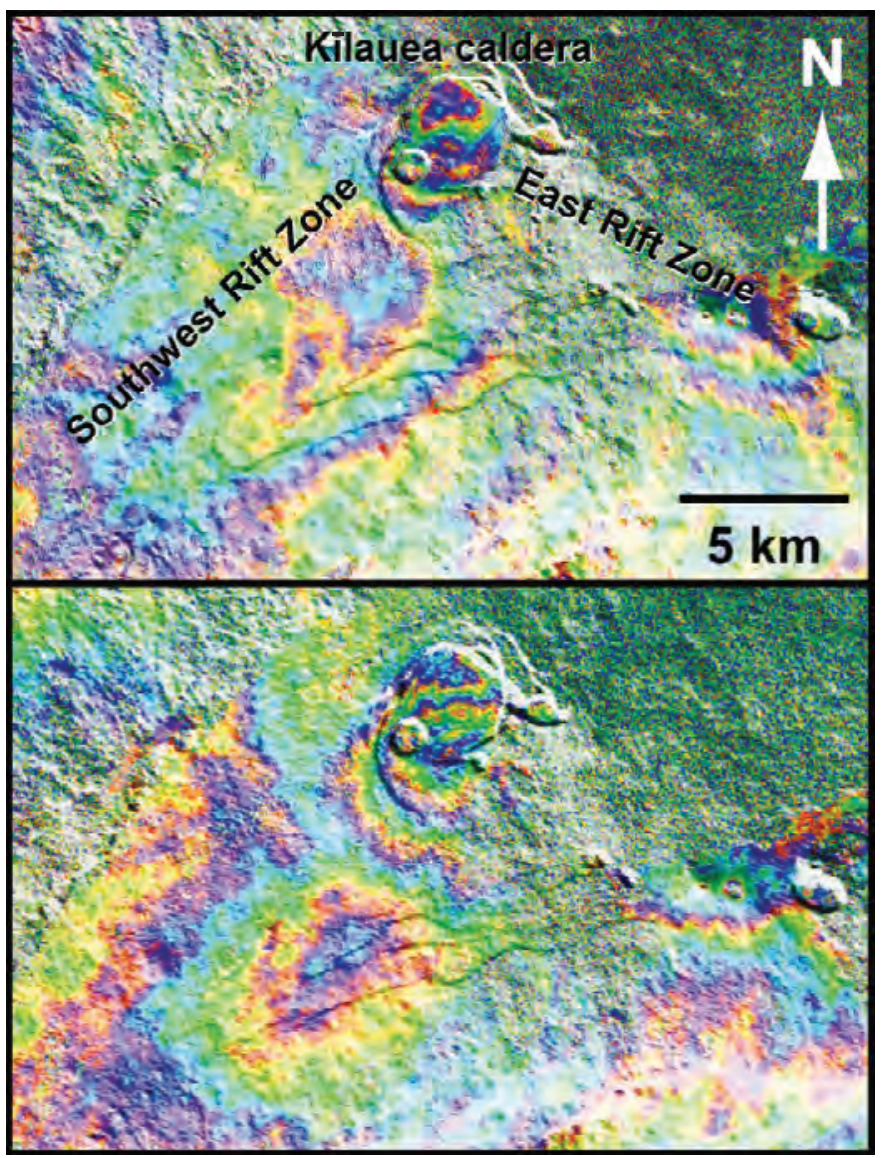

Figure 16. ENVISAT interferograms spanning from July 2, 2003, to September 29, 2004 (top) and from September 29, 2004, to December 28, 2005 (bottom). In both images, the fringes indicate uplift in the Kilauea caldera and subsidence of both the southwest and east rift zones. One fringe of color is equivalent to $2.76 \mathrm{~cm}$ of line-of-sight surface deformation. Note that between the two time periods, the caldera uplift intensified and migrated slightly south. 
rates $(1 \mathrm{~Hz})$, allowing transient deformation events with periods of minutes to hours to be recognized (Larson and others, 2003; Langbein and Bock, 2004; Mattia and others, 2004). As continuous deformation data become available at higher rates, the lines between seismology (with resolution typically on the order of seconds to minutes) and geodesy (with resolution typically on the order of hours to days) will blur. The merging of these traditionally independent fields is already occurring at volcanoes due to, for example, the use of borehole instrumentation, including strainmeters and seismometers (Mattioli and others, 2004; Voight and others, 2006; Mattioli and others, 2007). At Kīlauea, borehole strainmeters have already revealed previously unknown relations between magmatic activity and ground-water levels (Hurwitz and Johnston, 2003).

It is difficult to predict what new volcano deformation monitoring techniques might be introduced in the coming decades. Scientists measuring EDM lines across Mauna Loa's caldera at 13,000 feet elevation during frigid nights in the 1970 s could probably not imagine that, in about 20 years, GPS technology would provide three-dimensional positioning on a continuous basis, or that within 40 years, satellites would track deformation from space without the need for ground-based equipment. Some emerging technologies offer a glimpse at what the future may hold. As of this writing, ground-based laser scanning (also called terrestrial or tripod lidar) is showing promise as a method for characterizing $\mathrm{cm}$-scale deformation with excellent spatial resolution (see, for example, Byrnes and others, 2007). Lidar is limited, however, by poor atmospheric conditions, which are common at volcanoes. Groundbased radar overcomes this limitation and has seen successful application at Soufrière Hills volcano, Montserrat (Wadge and others, 2005).

Because of their accessibility, diversity of surface-deformation types, and eruption frequency, Kîlauea and Mauna Loa will continue to be important testing grounds for new methods in volcano geodesy. The insights gained through future geodetic investigations in Hawai $i$ will address an array of unresolved problems in volcanology and will also raise even more questions that will challenge the next generation of volcano geodesy explorers.

\section{References Cited}

Amelung, F., Yun, S.-H., Walter, T.R., Segall, P., and Kim, S.-W., 2007, Stress control of deep rift intrusion at Mauna Loa volcano, Hawaii: Science, v. 316, p. 1026-1030.

Barnard, W.M., ed., 1990, Mauna Loa, a source book-historical eruptions and exploration, volume one, from 1778 through 1907: Fredonia, NY, Walther M. Barnard, 353 p.

Bevens, D., 1992, On the Rim of Kilauea-Excerpts from the Volcano House Register: Hawai i National Park, Hawai i Natural History Association, 168 p.
Bevens, D., Takahashi, T.J., and Wright, T.L., eds., 1988, The early serial publications of the Hawaiian Volcano Observatory, v. 1: Hawai i National Park, Hawai i Natural History Association, $565 \mathrm{p}$.

Bishop, A., 1827, Visit to the volcano: Missionary Herald, v. 23, p. 53.

Brigham, W.T., 1908, Kilauea in September, 1908: Hawaiian Annual for 1909 , p. 140-144.

Brooks, B.A., Foster, J.H., Bevis, M., Frazer, L.N., Wolfe, C.J., and Behn, M., 2006, Periodic slow earthquakes on the flank of Kilauea volcano, Hawai'i: Earth and Planetary Science Letters, v. 246, p. 207-216.

Byrnes, J.M., Finnegan, D.C., Nicoll, K., and Anderson, S.W., 2007, Ground-based LiDAR measurements of actively inflating pahoehoe flows, Kilauea volcano, Hawaii-Implications for emplacement of basaltic units on Mars [abs.]: EOS, Transactions, American Geophysical Union, v. 88, Abstract P41A-04.

Cervelli, P.F., and Miklius, A., 2003, The shallow magmatic system of Kilauea volcano, chap. 9 of Heliker, C., Swanson, D.A., and Takahashi, T.J., eds., The Pu'u O'o-Kupaianaha eruption of Kilauea Volcano, Hawai $\mathrm{i}$-The first 20 years: U.S. Geological Survey Professional Paper 1676, p. 149-163.

Cervelli, P., Segall, P., Amelung, F., Garbeil, H., Meertens, C., Owen, S., Miklius, A., and Lisowski, M., 2002a, The 12 September 1999 Upper East Rift Zone dike intrusion at Kilauea Volcano, Hawai i: Journal of Geophysical Research, v. 107, doi:10.1029/2001JB000602.

Cervelli, P., Segall, P., Johnson, K., Lisowski, M., and Miklius, A., 2002b, Sudden aseismic fault slip on the south flank of Kilauea Volcano: Nature, v. 415, p. 1014-1018.

Clague, D.A., Hagstrum, J.T., Champion, D.E., Beeson, M.H., 1999, K\#lauea summit overflows-Their ages and distribution in the Puna District, Hawai i: Bulletin of Volcanology, v. 61 , p. $363-381$.

Coan, T., 1870, The volcano of Kilauea, and great earthquake waves: American Journal of Science, v. 49, p. 269-271.

Decker, R.W., 1965, Vertical ground displacements over the east rift of Kilauea Volcano, Hawai i [abs.]: EOS, Transactions, American Geophysical Union, v. 46, p. 185.

Decker, R.W., and Christiansen, R.L., 1984, Explosive eruptions of Kilauea Volcano, Hawai i, in National Research Council and others, eds., Explosive volcanism-inception, evolution, and hazards (Studies in geophysics): Washington, D.C., National Academy Press, p. 122-132. 
Decker, R.W., Hill, D.P., and Wright, T.L., 1966, Deformation measurements on Kilauea Volcano, Hawai i: Bulletin Volcanologique, v. 29, p. 721-731.

Decker, R.W., Koyanagi, R.Y., Dvorak, J.J., Lockwood, J.P., Okamura, A.T., Yamashita, K.M., and Tanigawa, W.R., 1983, Seismicity and surface deformation of Mauna Loa Volcano, Hawai i [abs.]: EOS, Transactions, American Geophysical Union, v. 64, p. 545-547.

Decker, R.W., and Wright, T.L., 1968, Deformation measurements on Mauna Loa Volcano, Hawai i: Bulletin Volcanologique, v. 32, p. 401.

Dieterich, J.H., and Decker, R.W., 1975, Finite element modeling of surface deformation associated with volcanism: Journal of Geophysical Research, v. 80, p. 4094-4102.

Douglas, D., 1834, Extract from a private letter addressed to Captain Sabine, R.A., F.R.S., by Mr. David Douglas, F.L.S., dated Woahoo (Sandwich Islands), 3d of May, 1834: Journal of the Royal Geographical Society of London, v. 4, p. 333-344.

Dutton, C.E., 1884, Hawaiian volcanoes: U.S. Geological Survey Annual Report 4, p. 75-219.

Dvorak, J., Delaney, P.T., Okamura, A.T., and Prescott, W.H., 1989, High-precision geodetic measurements on Hawaiian volcanoes using satellite geodesy [abs.]: New Mexico Bureau of Mines and Mineral Resources Bulletin 131, p. 78.

Dvorak, J.J., and Dzurisin, D., 1997, Volcano geodesy-the search for magma reservoirs and the formation of eruptive vents: Reviews of Geophysics, v. 35, p. 343-384.

Dzurisin, D., Anderson, L.A., Eaton, G.P., Koyanagi, R.Y., Lipman, P.W., Lockwood, J.P., Okamura, R.T., Puniwai, G.S., Sako, M.K., and Yamashita, K.M., 1980, Geophysical observations of Kilauea Volcano, Hawai i, 2-Constraints on the magma supply during November 1975-September 1977: Journal of Volcanology and Geothermal Research, v. 7, p. 241-269.

Eaton, J.P., 1959, A portable water-tube tiltmeter: Bulletin of the Seismological Society of America, v. 49, p. 301-316.

Ellis, W., 1825, Narrative of a tour through Owhyhee: London, H. Fisher, Son, and P. Jackson, 264 p.

Ferretti, A., Prati, C., and Rocca, F., 2001, Permanent scatterers in SAR interferometry: IEEE Transactions on Geoscience and Remote Sensing, v. 39, p. 8-20.

Finch, R.H., 1925, Tilting of the ground at Hawaiian Volcano Observatory: The Volcano Letter, v. 41, p. 1.

Finch, R.H., 1940, Engulfment at Kilauea Volcano: The Volcano Letter, v. 470, p. 1-2.
Finch, R.H., 1941, The filling in of Kilauea Crater: The Volcano Letter, v. 471, p. 1-3.

Fiske, R.S., and Kinoshita, W.T., 1969, Inflation of Kilauea Volcano prior to its 1967-1968 eruption: Science, v. 165, p. 341-349.

Gaddis, L., Mouginis-Mark, P., Singer, R., and Kaupp, V., 1989, Geologic analyses of shuttle imaging radar (SIR-B) data of Kilauea Volcano, Hawai i: Geological Society of America Bulletin, v. 101, p. 317-332.

Goodrich, J., 1831, Missionary Letters, 1816-1900: Hawaiian Mission Children's Society, v. 6, p. 1572-1582.

Haskell, R.C., 1860, Eruption of Mauna Loa, Sandwich Islands: American Journal of Science, v. 29, p. 301-302.

Hazlett, R.W., 2002, Geological field guide, Kilauea Volcano: Hawaii National Park, Hawai'i Natural History Association, $162 \mathrm{p}$.

Heliker, C., Kauahikaua, J., Sherrod, D.R., Lisowski, M., and Cervelli, P., 2003, The rise and fall of Pu`u 'O`o cone, 1983-2002, chap. 2 of Heliker, C., Swanson, D.A., and Takahashi, T.J., eds., The Pu'u Ō'ō-Kūpaianaha eruption of Kilauea Volcano, Hawai i-The first 20 years: U.S. Geological Survey Professional Paper 1676, p. 29-51.

Hitchcock, C.H., 1911, Hawai i and its volcanoes: Honolulu, Hawaiian Gazette Co., 314 p.

Hooper, A., Zebker, H., Segall, P., and Kampes, B., 2004, A new method for measuring deformation on volcanoes and other natural terrains using InSAR persistent scatterers: Geophysical Research Letters, v. 31, doi:10.1029/2004GL021737.

Hurwitz, S., and Johnston, M.J.S., 2003, Groundwater level changes in a deep well in response to a magma intrusion event on Kilauea Volcano, Hawai'i: Geophysical Research Letters, v. 30, doi:10.1029/2003GL018676.

Jachens, R.C., and Eaton, G.P., 1980, Geophysical observations of Kilauea Volcano, Hawai i, 1-Temporal gravity variations related to the 29 November, 1975, M=7.2 earthquake and associated summit collapse: Journal of Volcanology and Geothermal Research, v. 7, p. 225-240.

Jaggar, T.A., Jr., 1931, The crater of Mauna Loa: The Volcano Letter, v. 360, p. 1-4.

Jaggar, T.A., Jr., and Finch, R.H., 1924, The explosive eruption of Kilauea in Hawaii, 1924: American Journal of Science, v. 8, p. 353-374.

Johnson, D.J., 1987, Elastic and inelastic magma storage at Kilauea Volcano, chap. 47 of Decker, R.W., Wright, T.L., and Stauffer, P.H. eds., Volcanism in Hawaii: U.S. Geological Survey Professional Paper 1350, p. 1807-1820. 
Johnson, D.J., 1992, Dynamics of magma storage in the summit reservoir of Kilauea Volcano, Hawai i: Journal of Geophysical Research, v. 97, p. 1807-1820.

Kauahikaua, J., and Miklius, A., 2003, Long-term trends in microgravity at Kilauea's summit during the Pu`u 'O`oKupianaha eruption, chap. 10 of Heliker, C., Swanson, D.A., and Takahashi, T.J., eds., The Pu'u O'o-Kupaianaha eruption of Kilauea Volcano, Hawai i-The first 20 years: U.S. Geological Survey Professional Paper 1676, p. $165-171$.

King, J., 1785, A voyage to the Pacific Ocean (2d ed.): London, H. Hughs, v. 3, p. 100-113.

Kinoshita, W.T., Swanson, D.A., and Jackson, D.B., 1974, The measurement of crustal deformation related to volcanic activity at Kilauea Volcano, Hawai i, in Civetta, L., Gasparini, P., Luongo, G., and Rapolla, A., eds., Physical volcanology — developments in solid Earth geophysics 6: Amsterdam, Elsevier Scientific Publishing Co., p. 87-115.

Krivoy, H.L., and Eaton, J.P., 1961, Preliminary gravity survey of Kilauea Volcano, Hawai i: U.S. Geological Survey Professional Paper 424-D, p. D205-D208.

Langbein, J., and Bock, Y., 2004, High-rate real-time GPS network at Parkfield-utility for detecting fault slip and seismic displacements: Geophysical Research Letters, v. 31, doi:10.1029/2003GL019408.

Larson, K.M., Bodin, P., and Gomberg, J., 2003, Using 1-Hz GPS data to measure deformations caused by the Denali fault earthquake: Science, v. 300, p. 1421-1424.

Larson, R.G., 1999, The structure and rheology of complex fluids: New York, Oxford University Press, 688 p.

Lipman, P.W., Lockwood, J.P., Okamura, R.T., Swanson, D.A., and Yamashita, K.M., 1985, Ground deformation associated with the 1975 magnitude-7.2 earthquake and resulting changes in activity of Kilauea Volcano, Hawai i: U.S. Geological Survey Professional Paper 1276, 45 p.

Lloyd, C.R., 1964, Investigation of horizontal displacement of ground surface, Kilauea and Puna areas, Hawai i: U.S. Geological Survey unpublished report, $27 \mathrm{p}$.

Lockwood, J.P., Dvorak, J.J., English, T.T., Koyanagi, R.Y., Okamura, A.T., Summers, M.L., and Tanigawa, W.R., 1987, Mauna Loa 1974-1984-a decade of intrusive and extrusive activity, chap. 19 of Decker, R.W., Wright, T.L., and Stauffer, P.H. eds., Volcanism in Hawaii: U.S. Geological Survey Professional Paper 1350, p. 537-570.

Lu, Z., Wicks Jr., C., Kwoun, O.-I., Power, J.A., and Dzurisin, D., 2005, Surface deformation associated with the March 1996 earthquake swarm at Akutan Island, Alaska, revealed by C-band ERS and L-band JERS radar interferometry: Canadian Journal of Remote Sensing, v. 31, p. 7-20.
Lyman, C.S., 1851, On the recent condition of Kilauea: American Journal of Science, v. 12, p. 75-80.

Macdonald, G.A., 1959, The activity of Hawaiian volcanoes during the years 1951-1956: Bulletin Volcanologique, series 2, v. 22 , p. $3-70$.

Macdonald, G.A., and Eaton, J.P., 1955, The 1955 eruption of K\#lauea Volcano: The Volcano Letter, v. 529-530, p. 1-10.

Macdonald, G.A., and Eaton, J.P., 1957, Hawaiian volcanoes during 1954: U.S. Geological Survey Bulletin 1061-B, p. 17-72.

Macdonald, G.A., and Eaton, J.P., 1964, Hawaiian volcanoes during 1955: U.S. Geological Survey Bulletin 1171, p. $1-170$.

Massonnet, D., and Feigl, K.L., 1998, Radar interferomerty and its applications to changes in the earth's surface: Reviews of Geophysics, v. 36, p. 441-500.

Mattia, M., Rossi, M., Guglielmino, F., Aloisi, M., and Bock, Y., 2004, The shallow plumbing system of Stromboli Island as imaged from $1 \mathrm{~Hz}$ instantaneous GPS positions: Geophysical Research Letters, v. 31, doi: 10.1029/2004GL021281.

Mattioli, G.S., Voight, B., Linde, A.T., Sacks, I.S., Watts, P., Widiwijayanti, C., Young, S.R., Hidayat, D., Wlsworth, D., Malin, P.E., Shalev, E., Van Boskirk, E., Johnston, W., Sparks, R.S.J., Neuberg, J., Bass, V., Dunkley, P., Herd, R., Syers, T., Williams, P., and Williams, D., 2007, Unique and remarkable dilatometer measurements of pyroclastic flowgenerated tsunamis: Geology, v. 35, p. 25-28.

Mattioli, G.S., Young, S.R., Voight, B., Steven, R., Sparks, J., Shalev, E., Malin, P., Linde, A., Johnson, W., Hidayat, D., Elsworth, D., Dunkley, P., Herd, R., Neuberg, J., Norton, G., and Widiwijayanti, C., 2004, Prototype PBO instrumentation of CALIPSO Project captures world-record lava dome collapse on Montserrat Volcano: EOS, Transactions, American Geophysical Union, v. 85, p. 317, 323, 325.

Miklius, A., and Cervelli, P., 2003, Interaction between Kilauea and Mauna Loa: Nature, v. 421, p. 229.

Miklius, A, Cervelli, P., Sako, M., Lisowski, M., Owen, S., Segal, P., Foster, J., Kamibayashi, K., Brooks, B., 2005, Global positioning system measurements on the island of Hawai'i-1997 through 2004: U.S. Geological Survey Open File Report 2005-1425, 46 p.

Mitchell, H.C., 1930, Triangulation in Hawai' i: U.S. Coast and Geodetic Survey Special Publication no. 156, 219 p.

Moore, J.G., 1970, Relationship between subsidence and volcano load, Hawai i: Bulletin Volcanologique, v. 34, p. 562-576. 
Moore, J.G., 1987, Subsidence of the Hawaiian Ridge, chap. 2 of Decker, R.W., Wright, T.L., and Stauffer, P.H. eds., Volcanism in Hawaii: U.S. Geological Survey Professional Paper 1350, p. 85-100.

Okamura, A., 1975, The precision of recent tilt measurements at the Hawaiian Volcano Observatory [abs.]: EOS, Transactions, American Geophysical Union, Fall Meeting Supplement, v. 56, p. 1071.

Okamura, A.T., 1988, Water-tube and spirit-level tilt data, Hawaiian Volcano Observatory, 1958-1986: U.S. Geological Survey Open-File Report 88-237, 219 p.

Okamura, A.T., Dvorak, J.J., Koyanagi, R.Y., and Tanigawa, W.R., 1988, Surface deformation during dike propagation, chap. 6 of Wolfe, E.W., ed., The Puu Oo eruption of Kilauea Volcano, Hawaii-episodes 1 through 20, January 3, 1983, through June 8, 1984: U.S. Geological Survey Professional Paper 1463, p. 165-182.

Owen, S., Segall, P., Lisowski, M., Miklius, A., Denlinger, R., and Sako, M., 2000, Rapid deformation of Kilauea Volcano-global positioning system measurements between 1990 and 1996: Journal of Geophysical Research, v. 105, p. 18,983-18,998.

Pickering, C., 1844, chap. 5 of Wilkes, C., ed., Narrative of the United States Narrative Expedition during the years 1838, 1839, 1840, 1842, volume 4: Philadelphia, C. Sherman, p. $177-210$

Powers, H.A., 1946, Reanalyzing tilt records at the Hawaiian Volcano Observatory: The Volcano Letter, v. 492, p. 1-6.

Powers, H.A., 1947, Annual tilt pattern at the Hawaiian Volcano Observatory: The Volcano Letter, v. 495, p. 1-5.

Richter, D.H., Eaton, J.P., Murata, K.J., Ault, W.U., and Krivoy, H.L., 1970, Chronological narrative of the 1959-60 eruption of Kilauea Volcano, Hawai i: U.S. Geological Survey Professional Paper 537-E, p. E1-E73.

Rosen, P.A., Hensley, S., Zebker, H.A., Webb, F.H., and Fielding, E.J., 1996, Surface deformation and coherence measurements of Kilauea Volcano, Hawai i, from SIR-C radar interferometry: Journal of Geophysical Research, v. 101, p. 23,109-23,125.

Segall, P., Cervelli, P., Owen, S., Lisowski, M., and Miklius, A., 2001, Constraints on dike propagation from continuous GPS measurements: Journal of Geophysical Research, v. 106, p. 19,301-19,317.

Segall, P., Desmarais, E.K., Shelly, D., Miklius, A., and Cervelli, P., 2006, Earthquakes triggered by silent slip events on Kilauea volcano, Hawai i: Nature, v. 442, p. $71-74$.
Stearns, H.T., 1925, The explosive phase of Kilauea volcano, Hawaii, in 1924: Bulletin Volcanologique, v. 5-6, p. 193-208.

Stearns, H.T., and Macdonald, G.A., 1946, Geology and ground-water resources of the island of Hawai $\mathrm{i}$ : Hawai $\mathrm{i}$ (Terr.) Division of Hydrography Bulletin 9, 363 p.

Stewart, C.S., 1826, Volcano of Kirauea: American Journal of Science, v. 11, p. 362-376.

Strzelecki, P.E., de, 1838, Sandwich Islands-crater of Kirauea, Hawai i: Hawaiian Spectator, v. 10, p. 434-437.

Swanson, D.A., Duffield, W.A., and Fiske, R.S., 1976, Displacement of the south flank of Kilauea Volcano, the result of forceful intrusion of magma into the rift zones: U.S. Geological Survey Professional Paper 963, 39 p.

Tilling, R.I., 1976, The 7.2 magnitude earthquake, November 1975, island of Hawai i: Earthquake Information Bulletin, v. 8 , p. 5-13.

U.S. Coast and Geodetic Survey, E.S.S.A., 1969, Geographic positions and descriptions of triangulation stations, Hawaiian Islands: Washington, D.C., U.S. Government Printing Office, $219 \mathrm{p}$.

Voight, B., Linde, A.T., Sacks, I.S., Mattioli, G.S., Sparks, R.S.J., Elsworth, D., Hidayat, D., Malin, P.E., Shalev, E., Widiwijayanti, C., Young, S.R., Bass, V., Clarke, A., Dunkley, P., Johnston, W., McWhorter, N., Neuberg, J., and Williams, P., 2006, Unprecedented pressure increase in deep magma reservoir triggered by lava-dome collapse: Geophysical Research Letters, v. 33, doi:10.1029/2005GL024870.

Wadge, G., Macfarlane, D.G., Robertson, D.A., Hale, A.J., Pinkerton, H., Burrell, R.V., Norton, G.E., and James, M.R., 2005, AVTIS-A novel millimetre-wave ground based instrument for volcano remote sensing: Journal of Volcanology and Geothermal Research, v. 146, p. 307-318.

Waesche, H.H., 1940, Tilt changes at Kilauea: The Volcano Letter, v. 467, p. 1-7.

Waesche, H.H., 1942, Ground tilt at Kilauea Volcano: Journal of Geology, v. 50, p. 643-661.

Wilkes, C., 1845, Narrative of the U.S. Exploring Expedition during the years 1838-1842, volume 4: Philadelphia, Lee and Blanchard, $539 \mathrm{p}$.

Wilson, R.M., 1927a, Surveys around Kilauea: The Volcano Letter, v. 128, p. 1.

Wilson, R.M., 1927b, Geodetic measurements on Hawaii: The Volcano Letter, v. 107, p. 1.

Wilson, R.M., 1935, Ground surface movements at Kilauea Volcano, Hawai i: University of Hawai i Research Publication $10,56 \mathrm{p}$. 
Wingate, E.G., 1933, Puna triangulation: The Volcano Letter, v. 400 , p. $1-2$.

Wolfe, E.W., Garcia, M.O., Jackson, D.B., Koyanagi, R.Y., Neal, C.A., and Okamura, A.T., 1987, The Pu`u `O`o eruption of Kilauea Volcano, episodes 1-20, January 3, 1983, to June 8, 1984, chap. 17 of Decker, R.W., Wright, T.L., and Stauffer, P.H. eds., Volcanism in Hawaii: U.S. Geological Survey Professional Paper 1350, p. 471-508.

Wright, T., Parsons, B., and Fielding, E., 2001, Measurement of interseismic strain accumulation across the North Anatolian Fault by satellite radar interferometry: Geophysical Research Letters, v. 28, p. 2117-2120.

Wright, T., Parsons, B.E., and Lu, Z., 2004, Toward mapping surface deformation in three dimensions using InSAR: Geophysical Research Letters, v. 31, doi:10.1029/2003GL018827.
Wyss, M., and Koyanagi, R.Y., 1992, Seismic gaps in Hawai i: Bulletin of the Seismological Society of America, v. 82, p. 1373-1387.

Yamashita, K.M., 1981, Dry tilt, a ground deformation monitor as applied to the active volcanoes of Hawai i: U.S. Geological Survey Open-File Report 81-523, 14 p.

Yun, S., Segall, P., and Zebker, H., 2006, Constraints on magma chamber geometry at Sierra Negra volcano, Galapagos, based on InSAR observations: Journal of Volcanology and Geothermal Research, v. 150, p. 232-243.

Zebker, H.A., Rosen, P., Hensley, S., and Mouginis-Mark, P.J., 1996, Analysis of active lava flows on Kilauea Volcano, Hawai $i$, using SIR-C radar correlation measurements: Geology, v. 24, p. 495-498. 
